\title{
Changes in Climate Extremes over North Thailand, 1960-2099
}

\author{
Mohammad Badrul Masud, ${ }^{1}$ Peeyush Soni, ${ }^{2}$ Sangam Shrestha, ${ }^{3}$ and Nitin K. Tripathi ${ }^{3}$ \\ ${ }^{1}$ Global Institute for Water Security, School of Environment and Sustainability, University of Saskatchewan, \\ 11 Innovation Boulevard, Saskatoon, SK, Canada S7N 3 H5 \\ ${ }^{2}$ Agricultural Systems and Engineering, School of Environment, Resources and Development, Asian Institute of Technology, \\ P.O. Box 4, Klong Luang, Pathumthani 12120, Thailand \\ ${ }^{3}$ School of Engineering and Technology, Asian Institute of Technology, P.O. Box 4, Klong Luang, Pathumthani 12120, Thailand \\ Correspondence should be addressed to Mohammad Badrul Masud; badal_203@yahoo.com
}

Received 4 September 2015; Revised 10 January 2016; Accepted 14 January 2016

Academic Editor: Pedro Ribera

Copyright (c) 2016 Mohammad Badrul Masud et al. This is an open access article distributed under the Creative Commons Attribution License, which permits unrestricted use, distribution, and reproduction in any medium, provided the original work is properly cited.

\begin{abstract}
This study analyzes 24 climate extreme indices over North Thailand using observed data for daily maximum and minimum temperatures and total daily rainfall for the 1960-2010 period, and HadCM3 Global Climate Model (GCM) and PRECIS Regional Climate Model simulated data for the 1960-2100 period. A statistical downscaling tool is employed to downscale GCM outputs. Variations in and trends of historical and future climates are identified using the nonparametric Mann-Kendall trend test and Sen's slope. Temperature extreme indices showed a significant rising trend during the observed period and are expected to increase significantly with an increase in summer days and tropical nights in the future. A notable decline in the number of cool days and nights is also expected in the study area while the number of warm days and nights is expected to increase. There was an insignificant decrease in total annual rainfall, number of days with rainfall more than 10 and $20 \mathrm{~mm}$. However, the annual rainfall is projected to increase by $9.65 \%$ in the future $2011-2099$ period compared to the observed $1960-2010$ period.
\end{abstract}

\section{Introduction}

Analyses of climate change, climate variability, and their extremes are becoming more important as they clearly affect the human society and are essential for exploration of ecological and societal changes. One of the motivations for such analyses is to establish if and how global warming [1] might have influenced the climate on a global as well as on regional scale. In the environment and on the economic activities, the impact of climate change is reflected by the change of frequency, duration, and intensity of climate extreme events. After the third assessment report of the Intergovernmental Panel on Climate Change (IPCC), projections and detection of climate change are no longer relegated to global averages and have expanded to include extremes [2]. Various climate extreme events such as more recurrent and more intense droughts, floods, cyclones, and extreme rainfall events pose increasing and, oftentimes, limitless threats to environment, water resources, and agricultural production $[3,4]$.
General Circulation Models (GCMs) provide a reasonable basis for estimating future climates; however, outputs from GCM cannot be applied directly in many environmental and water resources protection studies because of some limitations, which include poor representation and simulation of local-scale processes and coarse spatial resolution. Therefore, these issues can be addressed by downscaling approaches. First approach of downscaling (statistical downscaling) climate data is through the use of statistical regressions that establish the relationship between large-scale variables, such as the driving factors derived from GCMs, to local level climate conditions. In the second approach (dynamical downscaling) Regional Climate Models (RCMs) are embedded into GCMs. The RCM is essentially a numerical model in which GCMs are used to fix boundary conditions. So, applying a downscaling technique is recommended for regional-scale analysis in IPCC-AR4 [5]. More recently, downscaling is widely applied in climatology for scenario construction and 
simulation/prediction of mean, minimum, and maximum air temperature and rainfall [6-8].

A number of investigations have attempted to identify observed and projected future changes in climate extremes on a global scale (e.g., [9-12]). A study on the variability in occurrence of extreme climate events at a global scale during the second half of the twentieth century [9] showed general increase in warm nights, decrease in the number of frost days, more frequent heavy rainfall events, less frequent cold temperature extremes, and decrease in the intra-annual extreme temperature range. Alexander et al. [10] showed that over $70 \%$ of global land area observed significant increase in the annual occurrence of warm nights and significant decrease in occurrence of cold nights. Projected changes in precipitation and dryness extremes are more ambiguous than that in temperature extremes at the end of 21st century [11]. Another study by Donat et al. [12], a research to improve global gridded dataset of extreme indices (HadEX to HadEX2, [10]), showed widespread significant changes in temperature extremes with warming especially for those indices derived from minimum temperature. Precipitation also showed similar changes but the changes were much more spatially heterogeneous compared to temperature changes.

A few studies have examined trends in climate extremes, other than changes in mean values across the Southeast Asia. Hence, little is known about trends in extremes of temperature and rainfall in this region. Manton et al. [13] analysed climate extreme indices for historical period in the Southeast Asia and South Pacific. Regional studies across the AsiaPacific region have shown significant increases in occurrences of annual number of hot days and warm nights and decreases in occurrences of annual number of cool days and cold nights over the past few decades (e.g., $[13,14])$. Results from Manton et al. [13] revealed significant decrease in the number of rainy days, significant increase in the proportion of total rainfall from extreme rainfall, significant increase in the minimum and maximum temperature, increase in the number of warm nights, and decrease in the number of cold nights and cool days at Nan Province of North Thailand. Chinvanno et al. [15] developed high-resolution climate scenarios using PRECIS (Providing Regional Climates for Impact Studies) RCM and showed that, during the observed period, most part of the North and Northeastern Thailand had 3-4 hot months over the year, while the Central Plain and the Southern Region had slightly longer summertime. Preliminary finding on MM5-RCM simulations of future projection by Kreasuwan [16] during 2010-2029 revealed that the average temperature in Thailand will increase slightly, and this trend will continue further in the future (during 2040-2059). In a study of Southeast Asia START (System for Analysis, Research and Training) Regional Centre (SEA START RC) [17], it was found that the night time temperature will get warmer than the daytime temperature by the 20452065 period. For the Northern mountainous and valley zone, annual average maximum and minimum temperature are expected to rise from 32.41 to $35.82^{\circ} \mathrm{C}$ and 20.43 to $24.82^{\circ} \mathrm{C}$, respectively, when compared to the median value among the results from 8 GCMs.
North Thailand is a critical area for a number of regional sustainable developmental issues. The mountainous landscape has relatively high forest cover. It contains the upper reaches of most of the watersheds feeding into the Chao Phraya River system, including the largest one, the Ping River Basin (PRB, catchment area of about $35,000 \mathrm{~km}^{2}$ ). This basin is an important wet-season source of water stored in the downstream Bhumibol Reservoir (located in Tak Province of North Thailand), which serves irrigation and commercial users during a lengthy dry season when drought may be problematic [18]. The basin area was previously covered by subtropical forests that have been slowly converted to agricultural lands in the recent past due to a host of economic, social, and political drivers that have commonly been driving land-cover/land-use changes through montane mainland Southeast Asia [19]. Greater Chiang Mai city area experienced a farm-to-city transition where built-up areas increased from 9\% to over 33\% between 1989 and 2009 [20-22]. The effects of urbanization that include the construction of major ring roads and changes in the Ping River bank and floodplains are blamed for causing more serious floods in recent years [21, 23-25]. Flooding and mudslides affected a large area in North Thailand, including Chiang Mai, Chiang Rai, Phayao, and Mae Hong Song Provinces [26]. The 2011 Chao Phraya River flood that caused $\$ 45$ billion damage in Thailand highlights the difficulty of water management $[27,28]$. Despite today's popularization of irrigation, rainfed crop fields remain in a large part of North Thailand. Since this type of cultivation largely depends on weather conditions, it has potential vulnerability against future climate changes accompanied by global warming. Changes in climate extremes have relations and significant impact on all of the anthropogenic activities and natural hazards. These issues constituted the motivation for this research. The purpose of the study is not to find out the best climate model rather than identifying the past and future changes of climate extremes in the regional scale through different emission scenarios. Therefore, in this study, observed trends in temperature and rainfall extremes in North Thailand were investigated over the last 51 years. Also, to detect the possible changes of extremes up to the year 2100, assessments of regional climate projections were made, derived from PRECIS regional model and HadCM3 (Hadley Centre Coupled Model version 3) global model.

The paper is organized as follows. Section 2 presents an overview of the study area and data used in this research, followed by methodology in Section 3. In Section 4, results of various analyses are presented and finally conclusions of the study are given in Section 5.

\section{Study Area and Data Used}

2.1. Geography. Administratively as well as geographically Thailand has four regions, namely, the Northeastern, North, Central Plain, and Southern. This study focused on four provinces of North Thailand, namely, Chiang Mai, Chiang Rai, Lamphun, and Tak (Figure 1). These provinces cover an important drainage area of the PRB and have a significant impact on country's agricultural activities. The Ping River, a major tributary of the Chao Praya River, plays a vital role in 


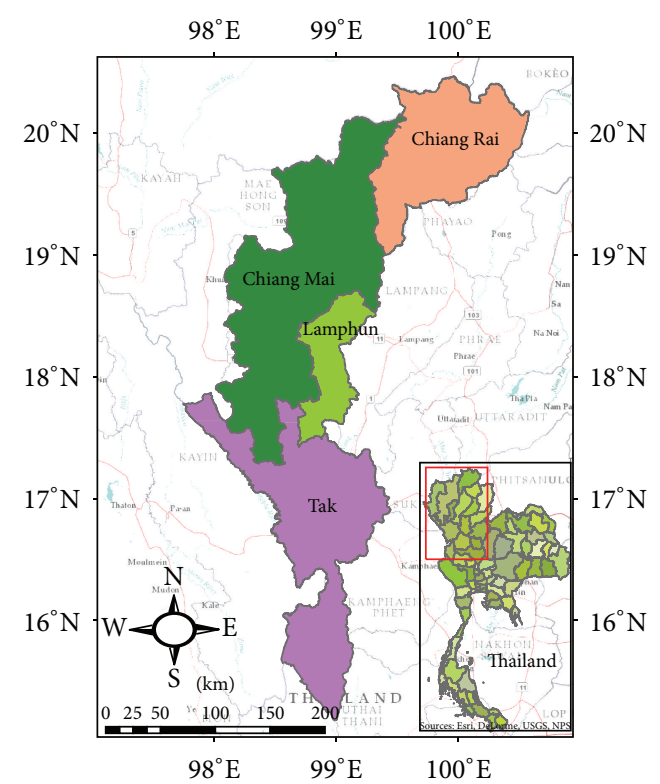

FIGURE 1: Location map of the study area in Thailand.

the country's economy. The Bumibol Dam on the Ping River adds additional importance to this region. Geographically, this region is mountainous and hilly with narrow valleys and occasional intermountain depressions forming a highly complex relief that merges across the international borders into Myanmar, Laos, and Yunnan (China), situated between $14.56^{\circ}-20.27^{\circ}$ North and $97.20^{\circ}-101.47^{\circ}$ East. These northsouth oriented hill ridges are parallel from west to east and intersected by some major valeeys, particularly those near Chiang Mai and Chiang Rai provinces. It experiences a strong monsoon climate with heavy summer rains between midMay or June and October but experiences dry weather in winter because of the northeast monsoon which is a main factor that controls the climate of this region. The northern part of the country usually experiences an extended period of warm weather because of its inland nature and tropical latitude zone [29]. In this region, the average annual temperature ranges from 20 to $34^{\circ} \mathrm{C}$ and the average annual rainfall varies between 1000 and $1800 \mathrm{~mm}$ depending on the location.

2.2. Data Used. Observed daily minimum temperature $\left({ }^{\circ} \mathrm{C}\right)$, maximum temperature $\left({ }^{\circ} \mathrm{C}\right)$, and total daily rainfall $(\mathrm{mm})$ data were collected from Thailand Meteorological Department for the period of 1960 to 2010 for Chiang Rai, Chiang Mai, and Tak provinces (Table 1). In Lamphun Province recording of climate data started from 1981 . Two sets of model data, each of which has two SRES scenarios (A2 and B2), were used in this study to the end of 21st century (19602099). The first set of data was collected from SEA START RC, where the climate data were downscaled using PRECIS RCM, which used ECHAM4 GCM data as an initial condition. Another set of climate data was produced by using a Statistical Downscaling tool (Statistical Downscaling Model (SDSM)) for the coarse resolution climate variables obtained from HadCM3 GCM.

\section{Methodology}

3.1. Downscaling Climate Data. The SDSM [30] calculates statistical relationships, based on multiple linear regression techniques, between large-scale (the predictors) and local (the predictand) climates. There are three implicit assumptions involved in statistical downscaling [31]. Firstly, the predictors are variables of relevance and are realistically modeled by the host GCM. Secondly, the empirical relationship is also valid under altered climatic conditions. Thirdly, the employed predictors fully represent the climate change signal. These relationships are developed using observed weather data, assuming that these relationships will remain valid in the future, that can be used to obtain downscaled local information for some future time period by driving the relationships with GCM-derived predictors. The observed large-scale predictors have been derived from the National Centers for Environmental Prediction (NCEP) reanalysis dataset [32]. This model becomes more accepted in recent years due to its applicability in a wide region and simplicity of establishing a relationship between predictor and predictand variables for future time zone [33].

Substantial differences may exist between projections from climate models; use of a single model does not provide results that adequately reflect the uncertainty inherent in regional climate scenario generation [34]. This study incorporates output of two models for a reliable projection of future climate. The SDSM is used to downscale the scenarios (A2 and B2) of HadCM3 by using the predictor variables developed by NCEP. HadCM3 was chosen for this analysis because it is one of four sets of climate model (HadCM2, HadCM3, CGCM2, and CSIRO) output provided with SDSM. The SDSM has successfully been used in several other downscaling studies [35-37]. Before forecasting the future climate variables, SDSM has been validated for the 1980-1989 period. The SEA START RC used ECHAM4 GCM (resolution $280 \times 280 \mathrm{~km}^{2}$; Max Plank Institute, Germany) for climate scenario generation and PRECIS RCM (developed at the Hadley Centre at the Meteorological Office, spatial resolution of $25 \times 25 \mathrm{~km}^{2}$ and emission scenarios B1, B2, A2, and A1FI) for downscaling the GCM data for specific region. The main reason to select PRECIS RCM in this research is that SEA START RC specially handles Southeast Asian region to predict more precise climate and freely provide data to researchers. Hence, A2 and B2 scenarios of PRECIS RCM data were collected from Southeast Asian START Regional Centre website (http://www.start.or.th/), where data are readily available to download.

$\mathrm{A} 2$ and $\mathrm{B} 2$ scenarios are the storylines which describe the development of different social, economic, technological, environmental, and policy dimensions. A2 is the future of the differentiated world, with emphasis on human wealth. Major underlying themes include strengthening regional cultural identities, with an emphasis on family values and local traditions, high population growth, and less concern for rapid economic development. B2 scenario emphasizes on sustainability and equity (Mixed Green Bag) and local solutions to economic, social, and environmental sustainability in the world [38]. 
TABLE 1: Detail information for meteorological station.

\begin{tabular}{lccccc}
\hline Station name & Station code & Data availability & Elevation $(\mathrm{m})$ & Latitude $\left({ }^{\circ} \mathrm{N}\right)$ & Longitude $\left({ }^{\circ} \mathrm{E}\right)$ \\
\hline Chiang Rai & 303201 & $1960-2010$ & 393 & 19.92 & 99.83 \\
Chiang Mai & 327501 & $1960-2010$ & 311 & 18.77 & 98.97 \\
Lamphun & 329201 & $1981-2010$ & 296 & 18.57 & 99.03 \\
Tak & 376201 & $1960-2010$ & 98 & 16.88 & 99.15 \\
\hline
\end{tabular}

3.2. Extreme Indices. Extreme climatic events, through the prolonged hot and cold spells, have numerous impacts on a nation which include significant loss of life, agriculture, production, water resources, forestry, energy, and infrastructure. It is essential to observe the climate extremes and continue to look for identification of changes in extremes as our resources and infrastructure are becoming more vulnerable to ruthless and extreme weather [39]. All of the extreme indices (13 for temperature and 11 for rainfall, Table 2) are calculated from the daily observation of temperature and rainfall by using RClimDex software [40]. These indices are recommended by the Climate Variability and Predictability (CLIVAR) Expert Team on Climate Change Detection, Monitoring, and Indices (ETCCDMI), adopted by the IPCC AR4. Data quality control is a necessary step before the analysis of climate variation, because erroneous outliers can impact seriously on trends [41]. For this, each data point was examined based on neighboring data, as well as on the understanding of the climate of the region. The data were edited if the problem is obvious (e.g., negative precipitation, 195 degrees changed to 19.5, and maximum temperature less than minimum temperature), set to missing if it is clearly a problem with unknown solution, or kept if deemed probably valid.

3.3. Trend Analysis. The trend of climate extremes presented in this paper is calculated by using the nonparametric MannKendall (MK) test $[39,40]$ that has been recommended by the World Meteorological Organization in assessing trends in environmental time series data [42]. The test has been widely used in trend detection analysis for hydrological and meteorological data [12, 43-47]. It is nearly as powerful as its parametric competitors. This method was chosen because it does not consider any distribution of the variable and some of the climate indices do not consider Gaussian distribution [12]. To estimate the true slope of an existing trend (as change per year), Sen's nonparametric method [48] is used. Sen's slope method gives a robust estimation of the trend and is used in various trend analyses of climate data [10, 12, 42]. Different significant levels $(10 \%, 5 \%, 1 \%$, and $0.1 \%)$ were used to consider a trend to be statistically significant.

\section{Results and Discussion}

In this section of the paper, results of various analyses ranging from trend analysis for observed period are presented first, followed by seasonal variation of climate parameters, model performance evaluation, and, finally, projected changes of climate parameters for the future period. Where necessary, link to other related studies is established in different subsections. For brevity, analyses of climate extremes results are presented for Chiang Rai Province and selected results for other provinces.

4.1. Trend Analysis for Observed Period (1960-2010). Trends and statistical results of temperature extremes are presented in Table 3, where increasing trend of temperature is experienced in the observed period. Both maximum and minimum temperature indices ( $\mathrm{TXx}, \mathrm{TX}, \mathrm{TNx}$, and $\mathrm{TNn}$ ) increased with significant trend, with the fact that minimum temperature was increased more than maximum temperature. The increasing trend of summer days (SU35) and tropical nights (TR25) favored the increment of temperature in the study area except in Chiang Rai Province. Warm days and warm nights (TX90p and TN90p) also increased with very high significant trend whereas cool days (TX10p) and cool nights (TN10p) decreased $[13,49]$ with the same trend along with mild to steep slope. Similar results were found by another study of Sharma and Babel [50] for Western Thailand. In the observed period, significant increases in warm extremes (TX90p, TN90p, SU35, TR25, and WSDI) were experienced in North Thailand where reverse trend was observed in case of cold extremes (TX10p, TN10p, and CSDI) which is also favored by the negative trend of diurnal temperature range (DTR) except in Lamphun Province (Figure 2). Zhang et al. [51] and Liu et al. [52] reported decreasing trend of the diurnal temperature range (DTR) because of rapid increase of the minimum temperature in recent decades. Based on MannKendall normalized test statistic $Z$ and Sen's slope value, Tak Province experienced relatively hot climate compared to any other provinces whereas Lamphun observed relatively cool climate.

All rainfall extremes showed insignificant trend except consecutive dry days (CDD) which was increasing with significant trend during the observed period of 1960-2010 (Table 3) in Chiang Rai and Tak provinces. Similar results were observed in another study of Sharma and Babel [50]. Except Lamphun Province, negative trends of PRCPTOT and R10 indicate that the rainfall was decreasing (Figure 2) over the study area. This less rainfall distribution supports the negative trend of consecutive wet days (CWD).

4.2. Seasonal Variation in Observed Period. During observed period, maximum temperature $\left(T_{\max }\right)$ showed a significant increasing trend in all seasons except spring which has an insignificant negative trend in all provinces. Minimum temperature $\left(T_{\text {min }}\right)$ increased significantly in Chiang Rai Province in all seasons, which is followed by Tak, Chiang Mai, and Lamphun provinces. The Mann-Kendall test statistic $Z$ showed that $T_{\min }$ has increasing trend more than $T_{\max }$. In mountainous provinces like Chiang Rai and Chiang Mai, the 

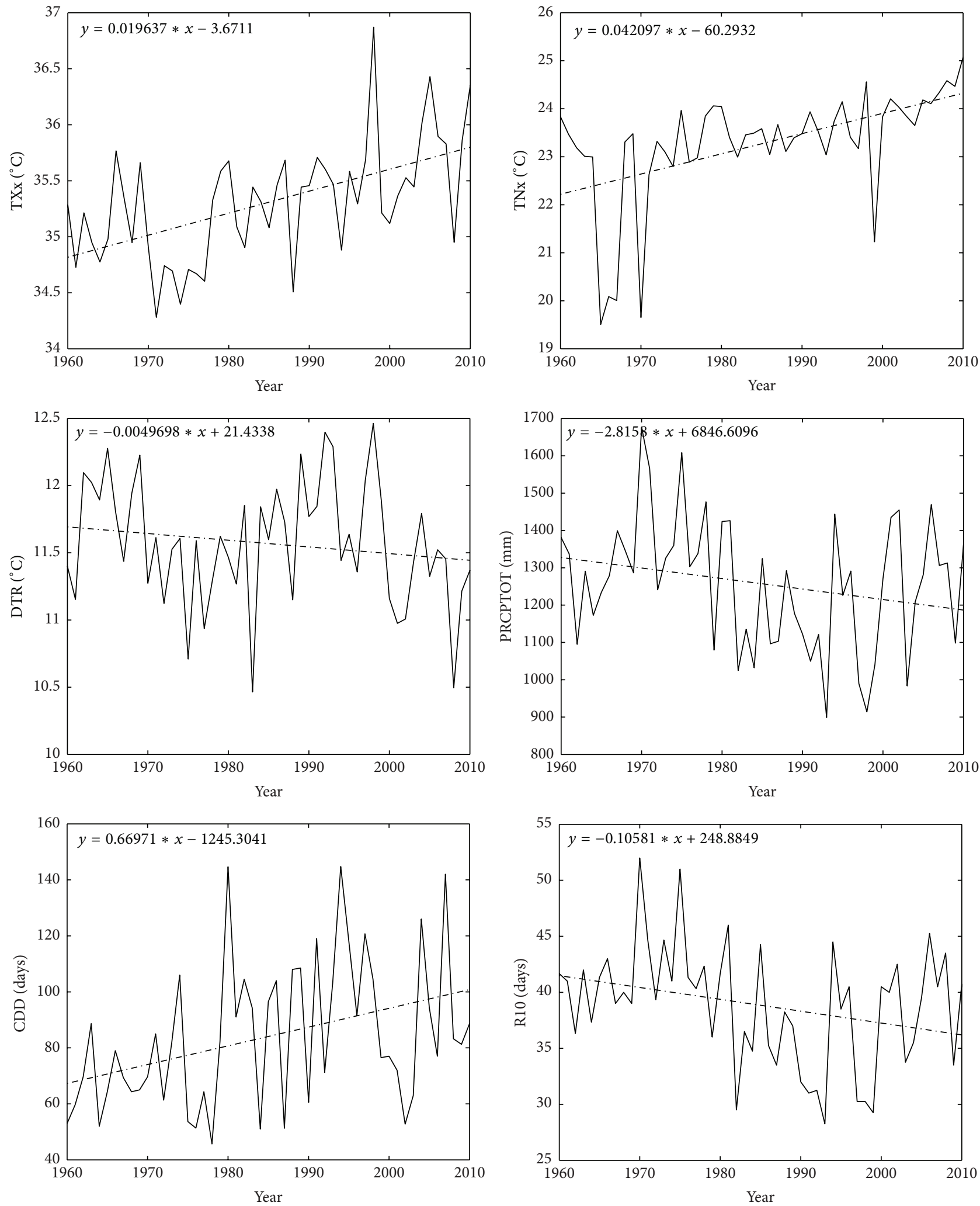

Figure 2: Monthly indices of temperature and rainfall extremes for the observed period 1960 to 2010 averaged across the study area. The dotted line is a trend-line computed by least square fit and corresponding regression equation is showed for each index. 
TABLE 2: Definition of extreme temperature and rainfall indices used in this study.

\begin{tabular}{|c|c|c|c|}
\hline ID & Indicator name & Definition & Unit \\
\hline \multicolumn{4}{|c|}{ Temperature indices } \\
\hline SU & Summer days & Annual count when daily max temperature $(\mathrm{TX})>35^{\circ} \mathrm{C}$ & Days \\
\hline TR & Tropical nights & Annual count when daily minitemperature $(\mathrm{TN})>25^{\circ} \mathrm{C}$ & Days \\
\hline TXx & Hottest day & Monthly maximum value of daily max temperature & ${ }^{\circ} \mathrm{C}$ \\
\hline $\mathrm{TNx}$ & Warmest night & Monthly maximum value of daily min temperature & ${ }^{\circ} \mathrm{C}$ \\
\hline TXn & Coldest day & Monthly minimum value of daily max temperature & ${ }^{\circ} \mathrm{C}$ \\
\hline $\mathrm{TNn}$ & Coldest night & Monthly minimum value of daily min temperature & ${ }^{\circ} \mathrm{C}$ \\
\hline TN10p & Cool nights & Percentage of days when $\mathrm{TN}<10$ th percentile & Days \\
\hline TX10p & Cool days & Percentage of days when $\mathrm{TX}<10$ th percentile & Days \\
\hline TN90p & Warm nights & Percentage of days when TN > 90th percentile & Days \\
\hline TX90p & Warm days & Percentage of days when TX > 90th percentile & Days \\
\hline DTR & Diurnal temp range & Monthly mean difference between TX and TN & ${ }^{\circ} \mathrm{C}$ \\
\hline WSDI & Warm spell duration index & $\begin{array}{l}\text { Annual count of days with at least } 6 \text { consecutive days when TX > } \\
\text { 90th percentile }\end{array}$ & Days \\
\hline CSDI & Cold spell duration index & $\begin{array}{l}\text { Annual count of days with at least } 6 \text { consecutive days when } \mathrm{TN}<10 \text { th } \\
\text { percentile }\end{array}$ & Days \\
\hline \multicolumn{4}{|c|}{ Rainfall indices } \\
\hline CDD & Consecutive dry days & Maximum number of consecutive days with $\mathrm{RR}<1 \mathrm{~mm}$ & Days \\
\hline CWD & Consecutive wet days & Maximum number of consecutive days with $\mathrm{RR} \geq 1 \mathrm{~mm}$ & Days \\
\hline PRCPTOT & Annual total rainfall & Annual total rainfall $(\mathrm{RR} \geq 1 \mathrm{~mm})$ & $\mathrm{mm}$ \\
\hline R10 & Moderate rainy days & Annual count of days when $\mathrm{PRCP} \geq 10 \mathrm{~mm}$ & Days \\
\hline R20 & Heavy rainy days & Annual count of days when $\mathrm{PRCP} \geq 20 \mathrm{~mm}$ & Days \\
\hline R100 & Very heavy rainy days & $\begin{array}{l}\text { Annual count of days when PRCP } \geq 100 \mathrm{~mm}, 100 \text { is user defined } \\
\text { threshold }\end{array}$ & Days \\
\hline R95p & Very wet days & Annual total PRCP when RR > 95th percentile & $\mathrm{mm}$ \\
\hline R99p & Extremely wet days & Annual total PRCP when RR > 99th percentile & $\mathrm{mm}$ \\
\hline RX1day & Max 1-day rainfall amount & Monthly maximum 1-day rainfall & $\mathrm{mm}$ \\
\hline Rx5day & Max 5-day rainfall amount & Monthly maximum consecutive 5-day rainfall & $\mathrm{mm}$ \\
\hline SDII & Simple daily intensity index & The ratio of annual total rainfall to the number of wet days $(\geq 1 \mathrm{~mm})$ & $\mathrm{mm} /$ day \\
\hline
\end{tabular}

temperature is observed to be higher than other provinces. A similar trend was identified by Zongxing et al. [41]. They also noticed the influence of topography on the regional pattern of temperature indices in Southwestern China; significant trends were on the Eastern Xizang Plateau and the Hengduan Mountains, while stations with insignificant trends were in the Sichuan Basin and on the Yunnan-Guizhou Plateau. There was no significant trend of rainfall detected during the observed period except winter (downward trend) and spring (upward trend) in Chiang Rai and Chiang Mai provinces, respectively (Table 4).

4.3. Model Performance Evaluation. Climate parameters can theoretically be projected by using appropriate GCM and RCM for intended place, but this does not imply that all the data will perfectly correspond to the real situation. Some data may be consistent with a particular time of month or year while other may not. To evaluate model performance, after screening all the 26 GCM variables in the SDSM model for significant correlation, 12 out of 26 variables were found significantly correlated $(p<0.05)$ to the observed temperature and rainfall data. Later on, these variables were used for the calibration of the model to develop a statistical relationship with the observed data and GCM output. For checking the consistency of observed and simulated maximum and minimum temperature and cumulative rainfall data, 1980s was taken as the base period. Results (Figure 3) revealed that none of the SRES of two models is fully unswerving with the observed data. However, based on the coefficient of determination, both PRECIS RCM and HadCM3 GCM have consistency with the base period. Similar performance was observed for HadCM3 GCM, which was downscaled using SDSM model in another study by Deb and Babel [53]. The maximum temperature difference between the observed and simulated values was about $\pm 0.5^{\circ} \mathrm{C}$, which imply that two models are reliable to simulate future data. Both models showed higher accuracy in case of predicting the rainfall compared to the base period. The average difference was $\pm 60 \mathrm{~mm}$ for all provinces except Tak which shows the maximum difference for HadCM3 GCM and minimum for PRECIS RCM. This performance evaluation is not to select the best model to simulate future scenarios rather than to 
TABLE 3: Observed trend of temperature and rainfall indices.

\begin{tabular}{|c|c|c|c|c|c|c|c|c|}
\hline \multirow{3}{*}{ Annual series } & \multicolumn{8}{|c|}{ Provinces } \\
\hline & \multicolumn{2}{|c|}{ Chiang Rai } & \multicolumn{2}{|c|}{ Chiang Mai } & \multicolumn{2}{|c|}{ Lamphun } & \multicolumn{2}{|c|}{ Tak } \\
\hline & MK Z & Sen's slope & MK Z & Sen's slope & MK $Z$ & Sen's slope & MK Z & Sen's slope \\
\hline & \multicolumn{8}{|c|}{ Temperature indices } \\
\hline SU35 & -0.12 & 0.000 & 0.87 & 0.143 & 1.46 & 0.500 & $2.47^{*}$ & 0.385 \\
\hline TR25 & -0.32 & & $2.54^{*}$ & 0.161 & 1.56 & 0.364 & $4.11^{* * *}$ & 0.857 \\
\hline TXx & $2.32^{*}$ & 0.011 & $3.28^{* *}$ & 0.019 & $2.44^{*}$ & 0.029 & $2.76^{* *}$ & 0.017 \\
\hline $\mathrm{TNx}$ & $5.71^{* * *}$ & 0.034 & $3.10^{* *}$ & 0.019 & $2.07^{*}$ & 0.021 & $3.53^{* * *}$ & 0.028 \\
\hline TXn & $2.71^{* *}$ & 0.025 & $1.80^{+}$ & 0.018 & -0.32 & -0.005 & $2.12^{*}$ & 0.017 \\
\hline $\mathrm{TNn}$ & $5.56^{* * *}$ & 0.038 & $5.50^{* * *}$ & 0.041 & $2.04^{*}$ & 0.018 & $5.20^{* * *}$ & 0.047 \\
\hline TN10p & $-6.20^{* * *}$ & -0.220 & $-4.82^{* * *}$ & -0.185 & - & - & $-4.21^{* * *}$ & -0.180 \\
\hline TX10p & $-3.35^{* * *}$ & -0.080 & $-1.99^{*}$ & -0.064 & - & - & $-3.17^{* *}$ & -0.093 \\
\hline TN90p & $6.64^{* * *}$ & 0.684 & $3.66^{* * *}$ & 0.224 & - & - & $4.34^{* * *}$ & 0.328 \\
\hline TX90p & $4.42^{* * *}$ & 0.290 & $3.66^{* * *}$ & 0.246 & - & - & $3.90^{* * *}$ & 0.234 \\
\hline DTR & $-3.16^{* *}$ & -0.017 & $-2.75^{* *}$ & -0.017 & 1.09 & 0.013 & -1.44 & -0.008 \\
\hline WSDI & $5.23^{* * *}$ & 0.545 & $3.81^{* * *}$ & - & - & - & $3.65^{* * *}$ & - \\
\hline \multirow[t]{2}{*}{ CSDI } & -1.00 & 0.000 & -0.644 & - & - & - & -1.06 & - \\
\hline & \multicolumn{8}{|c|}{ Rainfall indices } \\
\hline CDD & $1.67^{+}$ & 0.462 & 1.36 & 0.368 & 0.04 & 0.059 & $2.39^{*}$ & 0.676 \\
\hline CWD & -1.27 & -0.034 & 0.17 & 0.000 & 1.15 & 0.000 & -0.34 & 0.000 \\
\hline PRCPTOT & -0.02 & -0.192 & -0.84 & -1.747 & 0.57 & 4.092 & -0.34 & -0.594 \\
\hline $\mathrm{R} 10$ & -0.48 & -0.029 & -0.63 & -0.036 & 0.21 & 0.000 & -0.38 & 0.000 \\
\hline R20 & 0.33 & 0.000 & -1.29 & -0.056 & 0.04 & 0.000 & 0.26 & 0.000 \\
\hline R100 & -0.74 & - & 0.27 & - & 1.27 & & 1.32 & - \\
\hline R95P & 0.02 & 0.024 & 0.02 & 0.057 & 1.28 & 3.450 & 0.36 & 0.476 \\
\hline R99P & -1.54 & -0.362 & 1.20 & 0.000 & $2.55^{*}$ & 3.666 & 1.29 & 0.000 \\
\hline RX1day & -0.98 & -0.241 & $1.92^{+}$ & 0.429 & 1.23 & 0.495 & 1.02 & 0.260 \\
\hline RX5day & -1.29 & -0.428 & 0.65 & 0.221 & $2.12^{*}$ & 1.333 & 1.47 & 0.726 \\
\hline SDII & 0.55 & 0.012 & -0.46 & -0.006 & 0.46 & 0.008 & $1.90^{+}$ & 0.031 \\
\hline V. Heavy & -1.49 & - & -1.46 & - & 1.27 & - & 0.30 & - \\
\hline Heavy & 0.00 & - & 0.74 & - & 1.62 & - & 1.57 & - \\
\hline Moderate & 1.21 & -0.069 & -0.38 & -0.024 & 0.80 & 0.182 & -1.13 & -0.111 \\
\hline
\end{tabular}

${ }^{+}$Moderately significant, ${ }^{*}$ significant, ${ }^{* *}$ highly significant, and ${ }^{* * *}$ very highly significant.

Moderately significant $=90 \%$ level of confidence, significant $=95 \%$ level of confidence, highly significant $=99.9 \%$ level of confidence, and very highly significant $=99.99 \%$ level of confidence.

TABLE 4: Observed seasonal trend of temperature and rainfall.

\begin{tabular}{|c|c|c|c|c|c|c|c|c|c|}
\hline \multirow{2}{*}{ Climatic parameter } & \multirow{2}{*}{ Season } & \multicolumn{2}{|c|}{ Chiang Rai } & \multicolumn{2}{|c|}{ Chiang Mai } & \multicolumn{2}{|c|}{ Lamphun } & \multicolumn{2}{|c|}{ Tak } \\
\hline & & MK Z & Sen's slope & MK $Z$ & Sen's slope & MK $Z$ & Sen's slope & MK $Z$ & Sen's slope \\
\hline \multirow{4}{*}{$T_{\max }$} & Winter & $3.80^{* * *}$ & 0.034 & $3.28^{* *}$ & 0.028 & $2.68^{* *}$ & 0.057 & $3.20^{* *}$ & 0.032 \\
\hline & Spring & -0.80 & -0.006 & 0.31 & 0.003 & 0.00 & 0 & -0.08 & -0.001 \\
\hline & Summer & $2.08^{*}$ & 0.011 & $2.36^{*}$ & 0.016 & $1.82^{+}$ & 0.02 & $2.47^{*}$ & 0.016 \\
\hline & Autumn & $3.78^{* * *}$ & 0.026 & $3.01^{* *}$ & 0.019 & $2.07^{*}$ & 0.027 & $3.33^{* * *}$ & 0.021 \\
\hline \multirow{4}{*}{$T_{\min }$} & Winter & $3.62^{* * *}$ & 0.041 & $4.26^{* * *}$ & 0.053 & $2.25^{*}$ & 0.053 & $3.78^{* * *}$ & 0.05 \\
\hline & Spring & $6.22^{* * *}$ & 0.042 & $4.42^{* * *}$ & 0.044 & $2.43^{*}$ & 0.037 & $2.73^{* *}$ & 0.015 \\
\hline & Summer & $7.02^{* * *}$ & 0.033 & $3.48^{* * *}$ & 0.014 & 0.86 & 0.007 & $4.00^{* * *}$ & 0.019 \\
\hline & Autumn & $3.40^{* * *}$ & 0.025 & $2.45^{*}$ & 0.014 & -0.93 & -0.014 & $3.43^{* * *}$ & 0.022 \\
\hline \multirow{4}{*}{ Rainfall } & Winter & $-1.65^{+}$ & -0.004 & -0.23 & 0.000 & 0.20 & 0.000 & -0.45 & 0.000 \\
\hline & Spring & 1.62 & 0.020 & $1.66^{+}$ & 0.015 & 0.14 & 0.005 & 0.36 & 0.007 \\
\hline & Summer & -1.41 & -0.027 & -1.45 & -0.020 & 0.71 & 0.027 & 0.52 & 0.007 \\
\hline & Autumn & -0.15 & -0.002 & -0.93 & -0.012 & -0.82 & -0.023 & -0.34 & -0.007 \\
\hline
\end{tabular}

${ }^{+}$Moderately significant, ${ }^{*}$ significant, ${ }^{* *}$ highly significant, and ${ }^{* * *}$ very highly significant. 


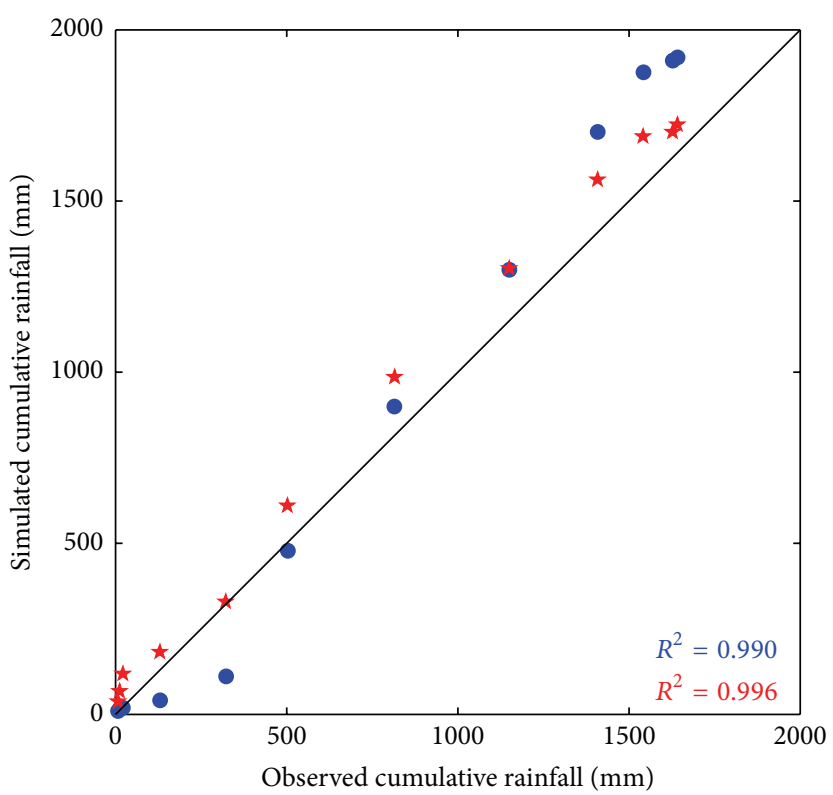

- PRECIS (A2)

$\star$ HadCM3 (A2)

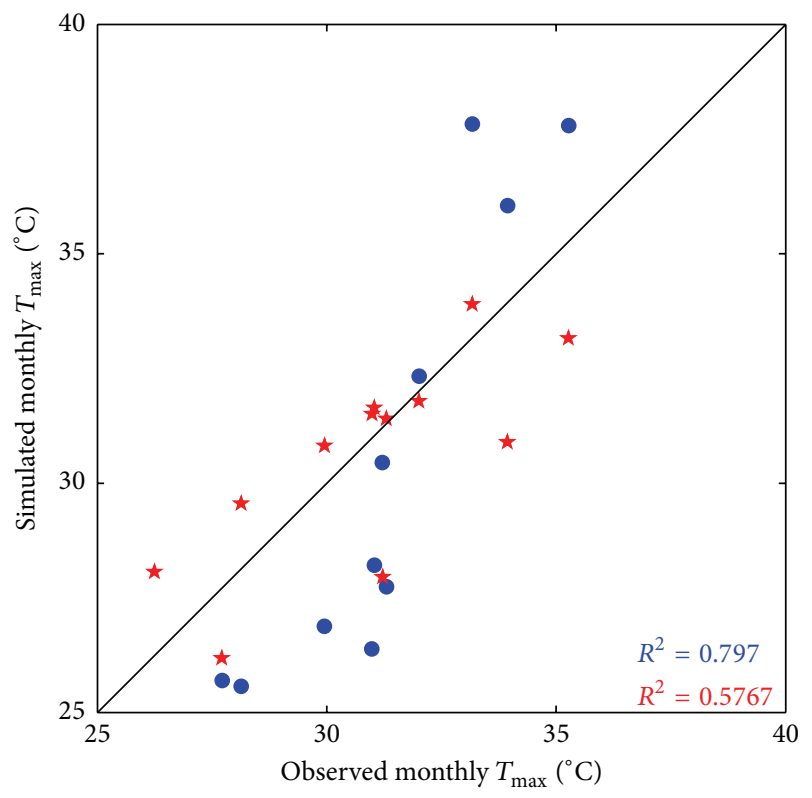

- PRECIS (A2)

$\star \operatorname{HadCM} 3$ (A2)

(a)

(b)

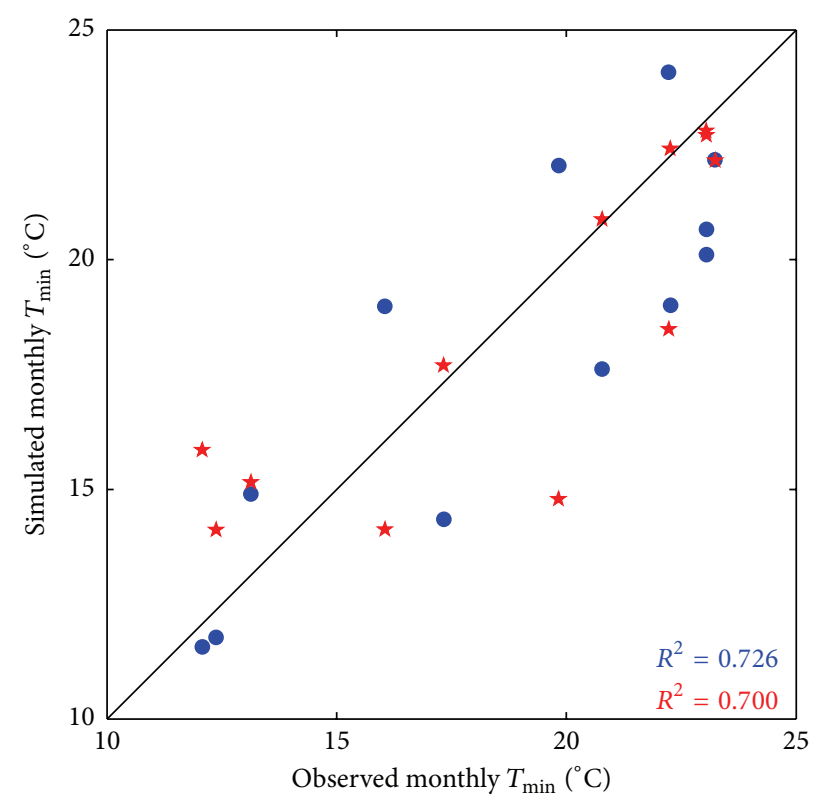

- PRECIS (A2)

$\star$ HadCM3 (A2)

(c)

Figure 3: Comparison of observed and simulated cumulative rainfall (a), monthly maximum temperature (b), and monthly minimum temperature (c) for 1980-1989 of Chiang Rai. Results for the case of PRECIS RCM are shown in blue color and those for the case of HadCM3 GCM in red.

provide more alternatives to know about the future climate and their extremes.

4.4. Future Temperature and Rainfall Scenarios. In this research, two IPCC scenarios are developed by using two climate models for the 1960-2099 period, which includes the observed 1960-2010 period and simulated 2011-2099 period for four provinces of North Thailand.

Average maximum and minimum temperature variations in the future period relative to the observed period are 

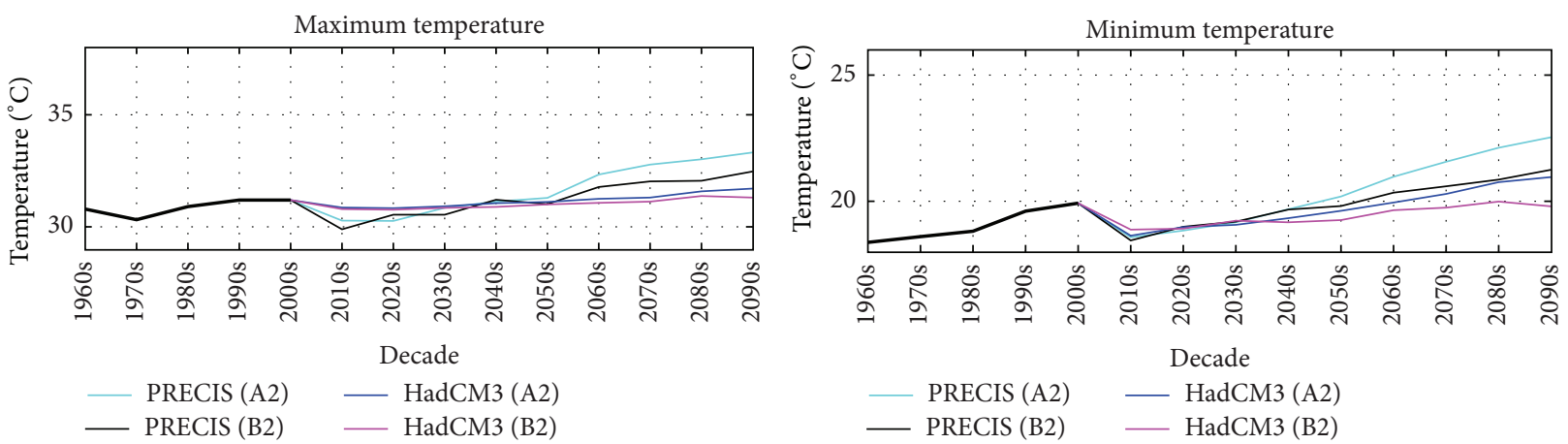

(a)
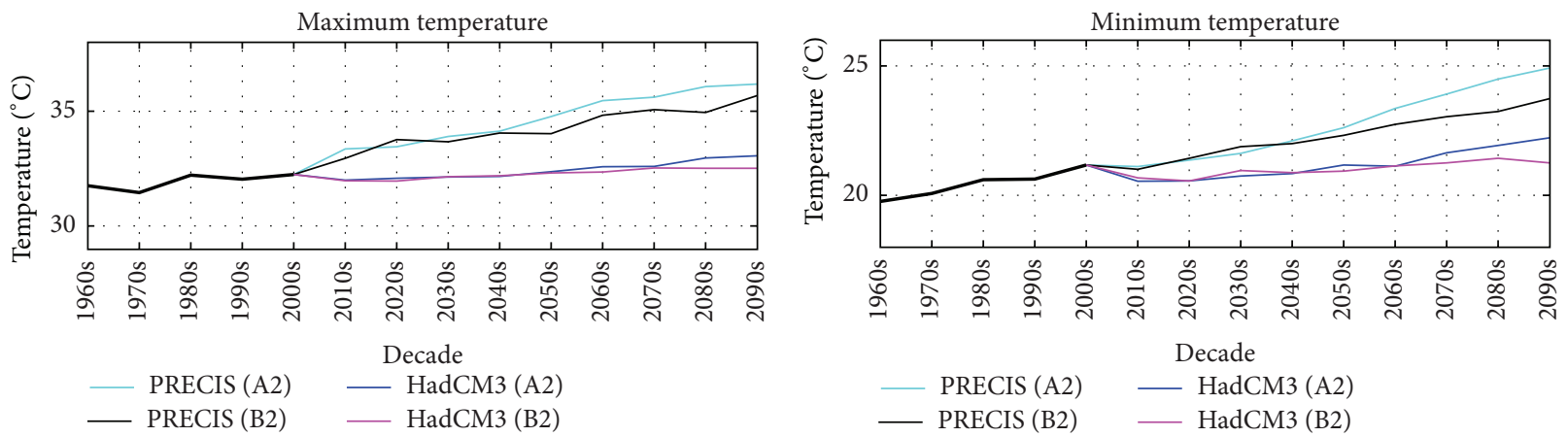

(b)
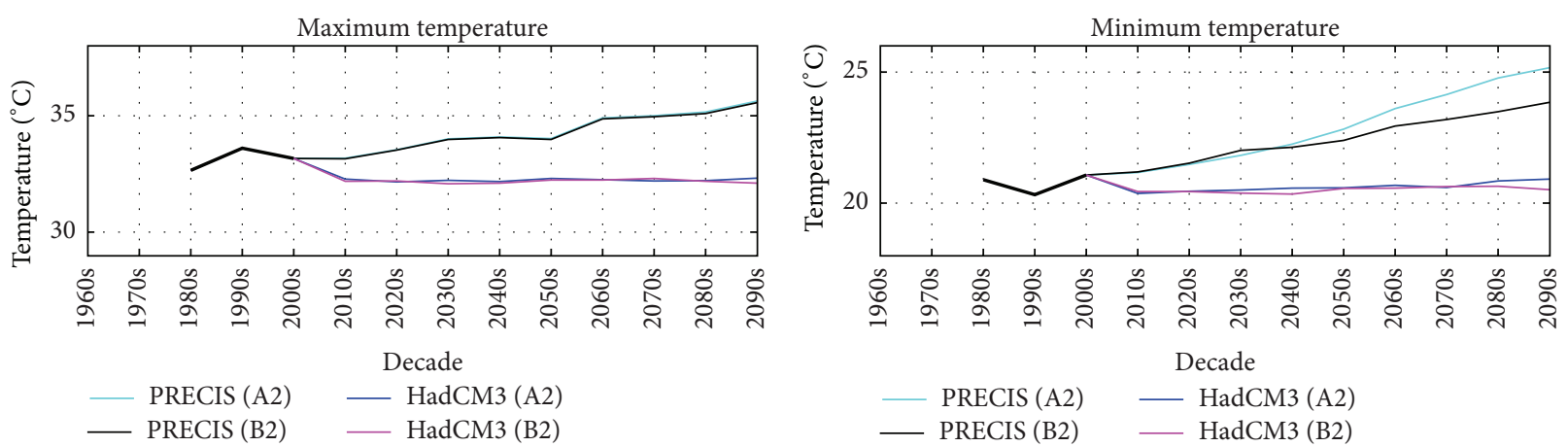

(c)
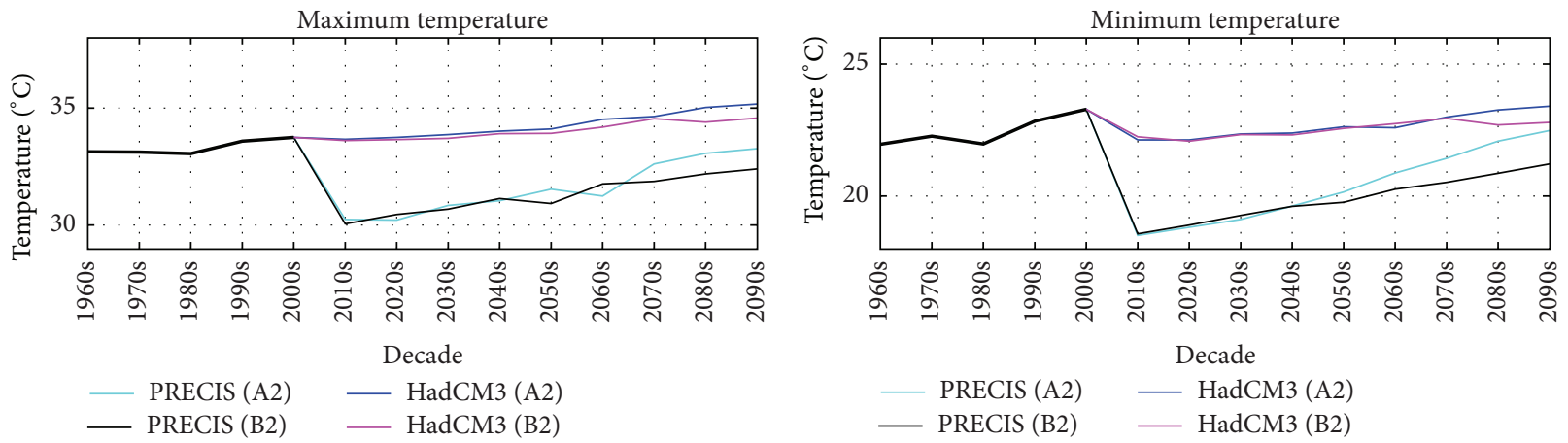

(d)

FIGURE 4: Average monthly maximum and minimum temperature variation in the future for (a) Chiang Rai, (b) Chiang Mai, (c) Lamphun, and (d) Tak. Black solid thick line up to 2000s indicates the observed data. 

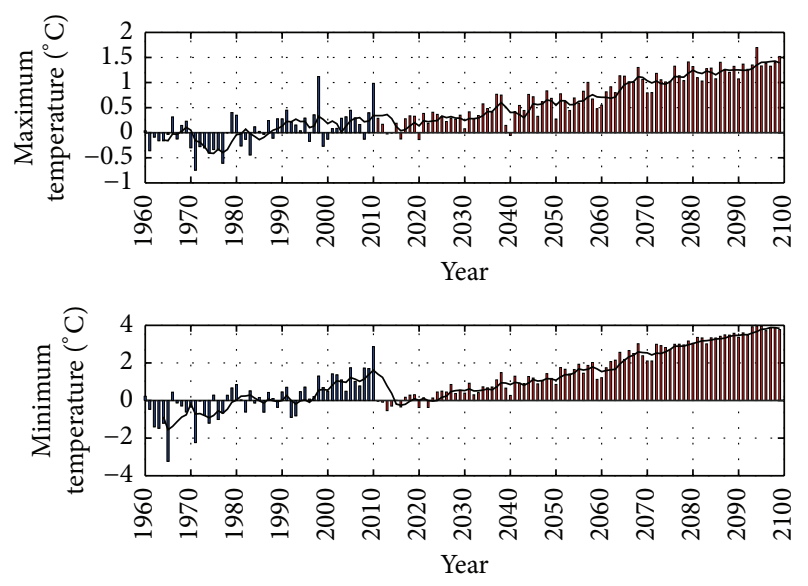

FIGURE 5: Multimodel and multiensembles temperature anomaly with respect to the control period 1970 to 2000. Results for the case of observed period (observed data) are shown in blue and those for the case of future period (simulated data) in red. The black solid is representing the 5-year moving average of anomalies.

plotted in Figure 4 for all provinces. None of the SRES is considered to have an outcome more likely than another but it is obvious that all demonstrate the continuation of the trends demonstrated by the historical data, which indicates increasing rates of temperature change for North Thailand. There are some exceptions like when HadCM3 GCM predicts a flat trend of maximum temperature, which is below the observed average maximum temperature. Similarly, PRECIS RCM did the same for Talk Province. These exceptions are similar for minimum temperature. The ensemble averaged maximum temperature for the future period (2011-2099) in Chiang Rai, Chiang Mai, Lamphun, and Tak is 31.29, $33.45,33.29$, and $34.96^{\circ} \mathrm{C}$, whereas the observed maximum temperature is $30.89,31.91,32.91$, and $33.32^{\circ} \mathrm{C}$, respectively. The ensemble averaged minimum temperature in the future period will increase by $0.87,1.42,0.93$, and $0.49^{\circ} \mathrm{C}$ relative to the observed period in Chiang Rai, Chiang Mai, Lamphun, and Tak, respectively. For both models and scenarios considered herein, the average monthly maximum and minimum temperature for all provinces average increases projected for the 2011-2099 period are 0.99 and $0.93^{\circ} \mathrm{C}$ above the observed period (1960-2010) mean of 32.26 and $20.66^{\circ} \mathrm{C}$, respectively. Erda et al. [54] reported that the temperature increase in China by the end of the twenty-first century may be between 3 and $4^{\circ} \mathrm{C}$, simulated by A2 scenario of PRECIS model. In Southeast Asia, mean warming of temperature will be $2.5^{\circ} \mathrm{C}$ in 2080-2099 relative to 1980-1999 [55]. According to IPCC ensemble-mean predictions, results estimated a net annual increase in temperature between $1.32^{\circ} \mathrm{C}$ (lowest emissions scenario $\mathrm{B} 1$ ) and $2.01^{\circ} \mathrm{C}$ (highest emissions scenario A1F1) for the 2040-2069 periods relative to the baseline 1961-1990 period [56]. It is clear from the above discussion that all scenarios indicate higher future temperature for North Thailand than what would result from a continuation of the trend from the historical record. Multimodel and multiensembles temperature anomaly, regionally averaged, showed that the trend of increasing monthly minimum temperature is higher than that of monthly maximum temperature (Figure 5).

As a result of higher interannual variability, prediction and identification of trends are less apparent for rainfall than temperature. However, each model and scenario evaluated project an increase in average annual rainfall of $9.65 \%$ for 2011-2099 compared to the observed average annual rainfall $1235 \mathrm{~mm}$. Total annual rainfall projections for the range of SRES suggest small differences (Figure 6) for Chiang Rai. For the period 2011-2099, the HadCM3 GCM and PRECIS RCM models project increase in total annual rainfall by $20.95 \%$ and $18.46 \%$, respectively, above the observed period mean of $1725 \mathrm{~mm}$ in Chiang Rai Province. PRECIS RCM projects increases in total rainfall but HadCM3 GCM projects decreases for Chiang Mai and Lamphun. This state is opposite for Tak Province where HadCM3 GCM projects increases in total rainfall. Future projection of monsoon rainfall is quite complicated due to the presence of aerosols (carbon aerosols) in the Asian monsoon [55]. However, the rainfall anomaly, regionally averaged, showed a continuous increasing trend of annual rainfall (Figure 7).

4.5. Projected Seasonal Variation. This section explains the ensemble average seasonal temperature and rainfall variation for 2020s, 2050s, and 2080s compared to the observed base period (1980s) (Tables 5 and 6). Daily maximum temperature in winter is projected to decrease during 2020s with respect to the base period. The daily maximum temperature projections of A2 and B2 scenarios of PRECIS RCM increase at higher rates in winter than that of the HadCM3 GCM and for the 2080s both scenarios of PRECIS RCM project daily maximum temperature increases by 2.33 and $1.40^{\circ} \mathrm{C}$, respectively. Similarly, both models project an increasing daily maximum temperature for spring, summer, and autumn seasons except 2020s, where only PRECIS RCM showed a decline of daily maximum temperature. Daily minimum winter temperature is going to increase in 2020s followed by 2050s and 2080s compared to the base period 1980s. The maximum increment $\left(4.99^{\circ} \mathrm{C}\right)$ is found for A2 scenario of PRECIS RCM in 2080s. In spring, PRECIS RCM projects an increase in daily minimum temperature in 2020s, 2050s, and 2080s regardless of scenarios but HadCM3 GCM projects the opposite. In summer and autumn, this minimum temperature is projected to increase in 2050s and 2080s by both scenarios of PRECIS and HadCM 3 models. It is noteworthy that the increasing rate of daily minimum temperature is higher during winter and summer than that of daily maximum temperature, whereas this fact is opposite in case of spring and autumn.

Seasonal variations of annual rainfall in the future decades with respect to the base period 1980s are tabulated in Table 6. In winter, A2 and B2 scenarios of HadCM3 GCM project an increase in annual rainfall by $80 \%$ in 2080 s, whereas PRECIS RCM's predictions are not consistent with this result. However, each scenario and model evaluated project a decrease in annual rainfall ranging from 13.84 to $61.10 \%$ in spring. However, in summer, the projection is opposite to spring where annual rainfall is increasing in 2020s, 2050s, and 2080s ranging from 19.83 to $46.55 \%$. For autumn, the annual rainfall projections for the range of 


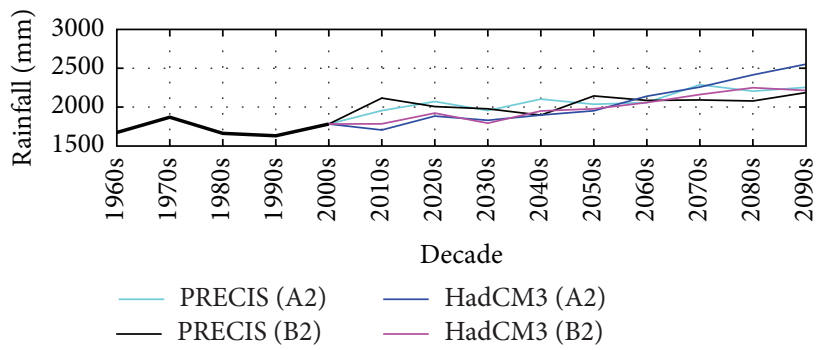

(a)

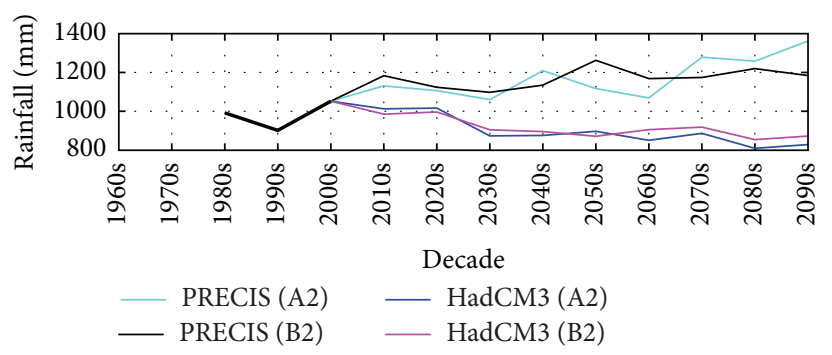

(c)

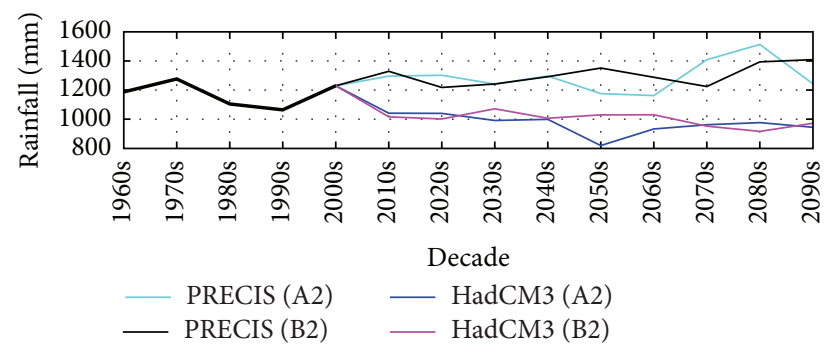

(b)

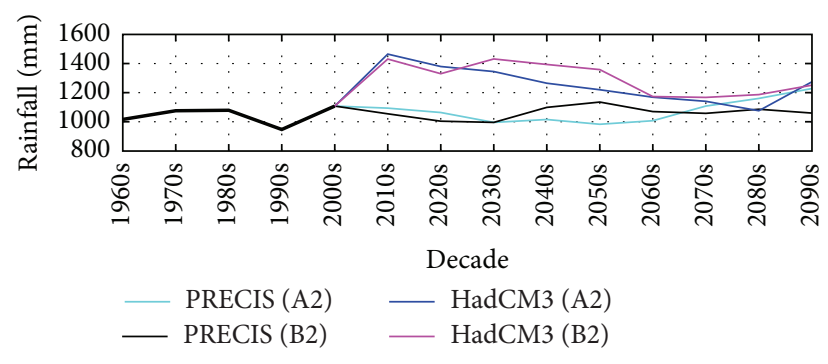

(d)

FIgURE 6: Annual rainfall variation in the future for (a) Chiang Rai, (b) Chiang Mai, (c) Lamphun, and (d) Tak. Black solid thick line up to 2000 s indicates the observed data.

TABLE 5: Average seasonal variation of daily maximum and minimum temperature in the future relative to 1980 s of observed period.

\begin{tabular}{|c|c|c|c|c|c|c|c|c|}
\hline \multirow{3}{*}{ Decade } & \multicolumn{4}{|c|}{ Winter $T_{\max }\left(T_{\min }\right)\left({ }^{\circ} \mathrm{C}\right)$} & \multicolumn{4}{|c|}{ Spring $T_{\max }\left(T_{\min }\right)\left({ }^{\circ} \mathrm{C}\right)$} \\
\hline & \multicolumn{2}{|c|}{ PRECIS } & \multicolumn{2}{|c|}{ HadCM3 } & \multicolumn{2}{|c|}{ PRECIS } & \multicolumn{2}{|c|}{ HadCM3 } \\
\hline & A2 & $\mathrm{B} 2$ & A2 & $\mathrm{B} 2$ & $\mathrm{~A} 2$ & $\mathrm{~B} 2$ & $\mathrm{~A} 2$ & B2 \\
\hline $2020 \mathrm{~s}$ & $-0.18(1.71)$ & $-0.23(1.41)$ & $-0.40(1.97)$ & $-0.33(1.86)$ & $2.67(1.03)$ & $2.98(1.18)$ & $0.39(-1.41)$ & $0.33(-1.46)$ \\
\hline 2050 s & $0.37(2.52)$ & $0.09(2.10)$ & $-0.01(2.61)$ & $-0.15(2.43)$ & $3.93(2.38)$ & $3.36(2.06)$ & $0.76(-0.76)$ & $0.57(-0.94)$ \\
\hline \multirow[t]{4}{*}{$2080 \mathrm{~s}$} & $2.33(4.99)$ & $1.40(3.42)$ & $0.86(4.02)$ & $0.30(3.15)$ & $4.62(4.07)$ & $4.52(3.24)$ & $1.02(0.13)$ & $0.85(-0.38)$ \\
\hline & \multicolumn{4}{|c|}{ Summer $T_{\max }\left(T_{\min }\right)\left({ }^{\circ} \mathrm{C}\right)$} & \multicolumn{4}{|c|}{ Autumn $T_{\max }\left(T_{\min }\right)\left({ }^{\circ} \mathrm{C}\right)$} \\
\hline & \multicolumn{2}{|c|}{ PRECIS } & \multicolumn{2}{|c|}{ HadCM3 } & \multicolumn{2}{|c|}{ PRECIS } & \multicolumn{2}{|c|}{ HadCM3 } \\
\hline & $\mathrm{A} 2$ & $\mathrm{~B} 2$ & $\mathrm{~A} 2$ & $\mathrm{~B} 2$ & $\mathrm{~A} 2$ & $\mathrm{~B} 2$ & $\mathrm{~A} 2$ & $\mathrm{~B} 2$ \\
\hline $2020 s$ & $0.88(-0.38)$ & $0.55(-0.07)$ & $0.74(0.32)$ & $0.64(0.40)$ & $-0.55(-0.69)$ & $-0.30(-0.67)$ & $0.46(-0.04)$ & $0.65(0.02)$ \\
\hline 2050 s & $1.99(1.09)$ & $1.20(0.70)$ & $1.40(1.01)$ & $0.94(0.79)$ & $0.94(0.81)$ & $0.52(0.47)$ & $1.13(0.50)$ & $0.85(0.39)$ \\
\hline 2080 s & $3.56(2.70)$ & $2.77(1.69)$ & $2.00(1.92)$ & $1.47(1.29)$ & $2.20(2.79)$ & $1.62(1.62)$ & $1.89(1.26)$ & $1.27(0.75)$ \\
\hline
\end{tabular}

TABLE 6: Average seasonal variation of annual rainfall in the future relative to 1980 s of observed period.

\begin{tabular}{|c|c|c|c|c|c|c|c|c|}
\hline \multirow{3}{*}{ Decade } & \multicolumn{4}{|c|}{ Winter rainfall (\%) } & \multicolumn{4}{|c|}{ Spring rainfall (\%) } \\
\hline & \multicolumn{2}{|c|}{ PRECIS } & \multicolumn{2}{|c|}{ HadCM3 } & \multicolumn{2}{|c|}{ PRECIS } & \multicolumn{2}{|c|}{ HadCM3 } \\
\hline & $\mathrm{A} 2$ & $\mathrm{~B} 2$ & $\mathrm{~A} 2$ & B2 & $\mathrm{A} 2$ & B2 & $\mathrm{A} 2$ & $\mathrm{~B} 2$ \\
\hline $2020 s$ & 25.97 & -6.45 & 40.83 & 32.29 & -44.35 & -54.20 & -15.20 & -21.64 \\
\hline 2050 s & -42.03 & 6.34 & 52.45 & 53.08 & -61.10 & -39.75 & -21.51 & -15.68 \\
\hline \multirow[t]{4}{*}{$2080 \mathrm{~s}$} & -29.89 & 3.44 & 70.89 & 79.38 & -32.08 & -64.30 & -16.01 & -13.84 \\
\hline & \multicolumn{4}{|c|}{ Summer rainfall (\%) } & \multicolumn{4}{|c|}{ Autumn rainfall (\%) } \\
\hline & \multicolumn{2}{|c|}{ PRECIS } & \multicolumn{2}{|c|}{ HadCM3 } & \multicolumn{2}{|c|}{ PRECIS } & \multicolumn{2}{|c|}{ HadCM3 } \\
\hline & $\mathrm{A} 2$ & B2 & $\mathrm{A} 2$ & $\mathrm{~B} 2$ & $\mathrm{~A} 2$ & $\mathrm{~B} 2$ & $\mathrm{~A} 2$ & $\mathrm{~B} 2$ \\
\hline 2020 s & 26.00 & 37.31 & 46.16 & 43.86 & 28.77 & 3.09 & -11.50 & -15.32 \\
\hline 2050 s & 25.48 & 46.55 & 32.35 & 35.33 & 31.48 & 14.34 & -32.24 & -21.16 \\
\hline $2080 \mathrm{~s}$ & 34.63 & 19.83 & 26.57 & 42.70 & 52.74 & 18.76 & -28.12 & -36.76 \\
\hline
\end{tabular}




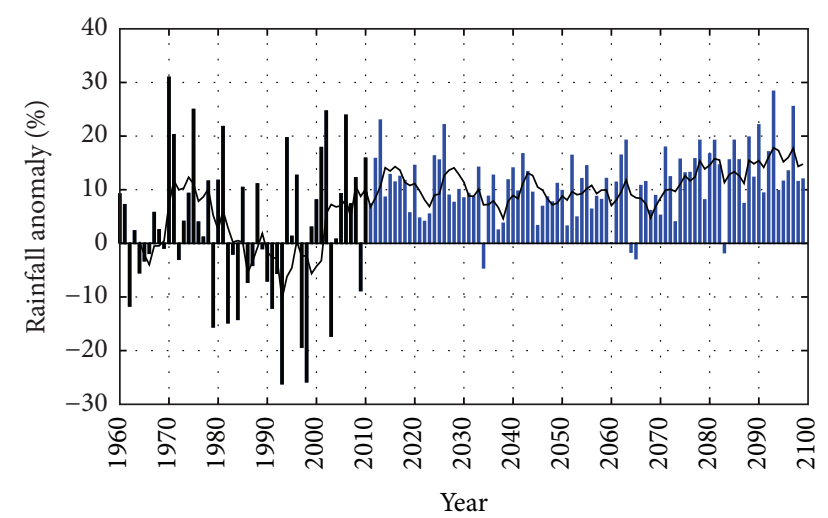

FIGURE 7: Multimodel and multiensembles rainfall anomaly with respect to the control period 1970 to 2000 . Results for the case of observed period (observed data) are shown in black and those for the case of future period (simulated data) in blue. The black solid is representing the 5-year moving average of anomalies.

SRES suggest big differences, because PRECIS RCM projects an increase in rainfall whereas HadCM3 GCM projects the opposite. Although both temperature and rainfall are rising in the future, there is no significant correlation found for temperature and rainfall in this region [57].

4.6. Trend Analysis for the Future Period. Figure 8 illustrates the two IPCC SRES for Chiang Rai Province as predicted by PRECIS RCM and HadCM3 GCM to see the trend of different warm and cold temperature extremes, developed by RClimDex, for the period of 2011-2099. Mann-Kendall test statistics $Z$ with Sen's slope are provided in Table 7 for the same province.

Almost all the temperature rising extreme indices (TX90p, TN90p, TXx, TNx, SU35, TR25, and WSDI) are increasing (Table 7 and Figure 8) with highly (very highly) significant trend, and the temperature falling indices (TX10p, TN10p, TXn, TNn, and CSDI) are decreasing with same trend for both SRES A2 and B2. Also, the values of MannKendall test statistic $Z$ and Sen's slope indicate that minimum temperature extremes ( $\mathrm{TNx}$ and $\mathrm{TNn}$ ) have stronger trend and steeper slope than maximum temperature extremes (TXx and TXn) and that the cold extremes (TX10p and TN10p) have weaker trend and milder slope than warm extremes (TX90p and TN90p). On an average, maximum and minimum temperature will increase by 1.56 and $2.24^{\circ} \mathrm{C}$, respectively, in 2090s as compared to 2020s (Figure 8). In contrast to summer days (SU35) and tropical nights (TR25), tropical nights will increase far beyond summer nights with the same level of significance. Hence, minimum temperature will increase more than the maximum temperature which is supported by the very high significant negative trend of diurnal temperature range (DTR); that is, daynight temperature variation will be smaller in future. Daily minimum temperatures are projected to increase faster than daily maximum temperatures, leading to a decrease in diurnal temperature range in the world [55].

The summary of the statistical analysis of rainfall extreme indices with their level of significance is tabulated in Table 8
TABLE 7: Trend of temperature indices for 2011-2099 period in Chiang Rai.

\begin{tabular}{|c|c|c|c|c|}
\hline \multirow[t]{2}{*}{$\begin{array}{l}\text { Annual } \\
\text { temperature series }\end{array}$} & $\begin{array}{l}\text { PRECIS } \\
\text { (A2) }\end{array}$ & $\begin{array}{l}\text { PRECIS } \\
\text { (B2) }\end{array}$ & $\begin{array}{l}\text { HadCM3 } \\
\text { (A2) }\end{array}$ & \multirow[t]{2}{*}{$\begin{array}{l}\text { HadCM3 } \\
\text { (B2) }\end{array}$} \\
\hline & \multicolumn{3}{|c|}{ MK test (Sen's slope) } & \\
\hline SU35 & $\begin{array}{l}7.42^{* * *} \\
(0.600)\end{array}$ & $\begin{array}{c}5.99^{* * *} \\
(0.416)\end{array}$ & $\begin{array}{c}6.79^{* * *} \\
(0.263)\end{array}$ & $\begin{array}{l}5.81^{* * *} \\
(0.188)\end{array}$ \\
\hline TR25 & $\begin{array}{c}9.97^{* * *} \\
(1.055)\end{array}$ & $\begin{array}{l}7.63^{* * *} \\
(0.589)\end{array}$ & $\begin{array}{c}11.03^{* * *} \\
(0.813)\end{array}$ & $\begin{array}{l}9.07^{* * *} \\
(0.400)\end{array}$ \\
\hline TXx & $\begin{array}{r}10.11^{* * *} \\
(0.052)\end{array}$ & $\begin{array}{l}9.07^{* * *} \\
(0.035)\end{array}$ & $\begin{array}{l}5.01^{* * *} \\
(0.010)\end{array}$ & $\begin{array}{c}5.84^{* * *} \\
(0.011)\end{array}$ \\
\hline $\mathrm{TNx}$ & $\begin{array}{c}11.40^{* * *} \\
(0.057)\end{array}$ & $\begin{array}{c}10.08^{* * *} \\
(0.037)\end{array}$ & $\begin{array}{c}9.76^{* * *} \\
(0.031)\end{array}$ & $\begin{array}{c}6.42^{* * *} \\
(0.016)\end{array}$ \\
\hline TXn & $\begin{array}{c}6.57^{* * * *} \\
(0.032)\end{array}$ & $\begin{array}{c}4.53^{* * *} \\
(0.021)\end{array}$ & $\begin{array}{c}6.25^{* * *} \\
(0.011)\end{array}$ & $\begin{array}{c}2.39^{*} \\
(0.004)\end{array}$ \\
\hline TNn & $\begin{array}{r}10.27^{* * *} \\
(0.050)\end{array}$ & $\begin{array}{l}7.89^{* * *} \\
(0.029)\end{array}$ & $\begin{array}{l}8.69^{* * *} \\
(0.028)\end{array}$ & $\begin{array}{r}4.68^{* * *} \\
(0.012)\end{array}$ \\
\hline TN10p & $\begin{array}{l}-7.56^{* * *} \\
(-0.054)\end{array}$ & $\begin{array}{l}-5.84^{* * *} \\
(-0.053)\end{array}$ & $\begin{array}{l}-9.15^{* * *} \\
(-0.073)\end{array}$ & $\begin{array}{l}-5.57^{* * *} \\
(-0.043)\end{array}$ \\
\hline TX10p & $\begin{array}{l}-6.52^{* * *} \\
(-0.068)\end{array}$ & $\begin{array}{l}-5.63^{* * *} \\
(-0.063)\end{array}$ & $\begin{array}{l}-5.69^{* * *} \\
(-0.037)\end{array}$ & $\begin{array}{l}-2.97^{* *} \\
(-0.019)\end{array}$ \\
\hline TN90p & $\begin{array}{r}11.12^{* * *} \\
(0.738)\end{array}$ & $\begin{array}{l}9.81^{* * *} \\
(0.560)\end{array}$ & $\begin{array}{c}11.34^{* * *} \\
(0.428)\end{array}$ & $\begin{array}{l}9.15^{* *} \\
(0.211)\end{array}$ \\
\hline TX90p & $\begin{array}{l}9.69^{* * *} \\
(0.534)\end{array}$ & $\begin{array}{l}7.91^{* * *} \\
(0.373)\end{array}$ & $\begin{array}{c}8.39^{* * *} \\
(0.117)\end{array}$ & $\begin{array}{l}7.10^{* *} \\
(0.066)\end{array}$ \\
\hline DTR & $\begin{array}{l}-6.11^{* * *} \\
(-0.011)\end{array}$ & $\begin{array}{l}-2.32^{*} \\
(-0.003)\end{array}$ & $\begin{array}{l}-9.32^{* * *} \\
(-0.018)\end{array}$ & $\begin{array}{c}-3.68^{* * *} \\
(-0.006)\end{array}$ \\
\hline WSDI & $\begin{array}{c}9.68^{* * *} \\
(1.750)\end{array}$ & $\begin{array}{l}7.71^{* * *} \\
(0.416)\end{array}$ & $\begin{array}{c}4.71^{* * *} \\
(-)\end{array}$ & $\begin{array}{c}3.12^{*} \\
(-)\end{array}$ \\
\hline CSDI & $\begin{array}{c}-3.11^{* *} \\
(-)\end{array}$ & $\begin{array}{c}-4.39^{* * *} \\
(-)\end{array}$ & $\begin{array}{c}-0.22 \\
(-)\end{array}$ & $\begin{array}{l}0.00 \\
(-)\end{array}$ \\
\hline
\end{tabular}

${ }^{+}$Moderately significant, ${ }^{*}$ significant, ${ }^{* *}$ highly significant, ${ }^{* * *}$ very highly significant, and ( ) = Sen's slope.

and their temporal trends are illustrated in Figure 9. The consecutive dry days (CDD) are indicating less rainfall in the study area. This extreme index is projected to decrease by an ensemble average of 1.38 days/year. The trend of annual total rainfall (PRCPTOT) reveals a very high significant increasing trend except B2 scenario of PRECIS RCM. This indicates that the study area will receive more rainfall in the future. Number of days with rainfall $\geq 10 \mathrm{~mm}$ (R10) and $\geq 20 \mathrm{~mm}$ (R20) are indicators of moderate and heavy rainfall. Both of these indices are projected to increase significantly. However, R20 will increase with higher trend than that of R10. Two important measures of extreme rainfall are the percentage of total rainfall due to events above the 95th and 99th percentiles (R95p and R99p). Results revealed that both indices increase with the significant trend. The sign of the trend for the annual total rainfall is compared with the sign of the trends in the R99p index. At a station where the annual amount decreases, negative R99p trends are indicative of a large contribution of the extremes and vice versa [50]. The maximum event intensity indices (RX1day and RX5day) show a significant increasing trend, whereas all scenarios of both models show a very high significant trend for RX5day 

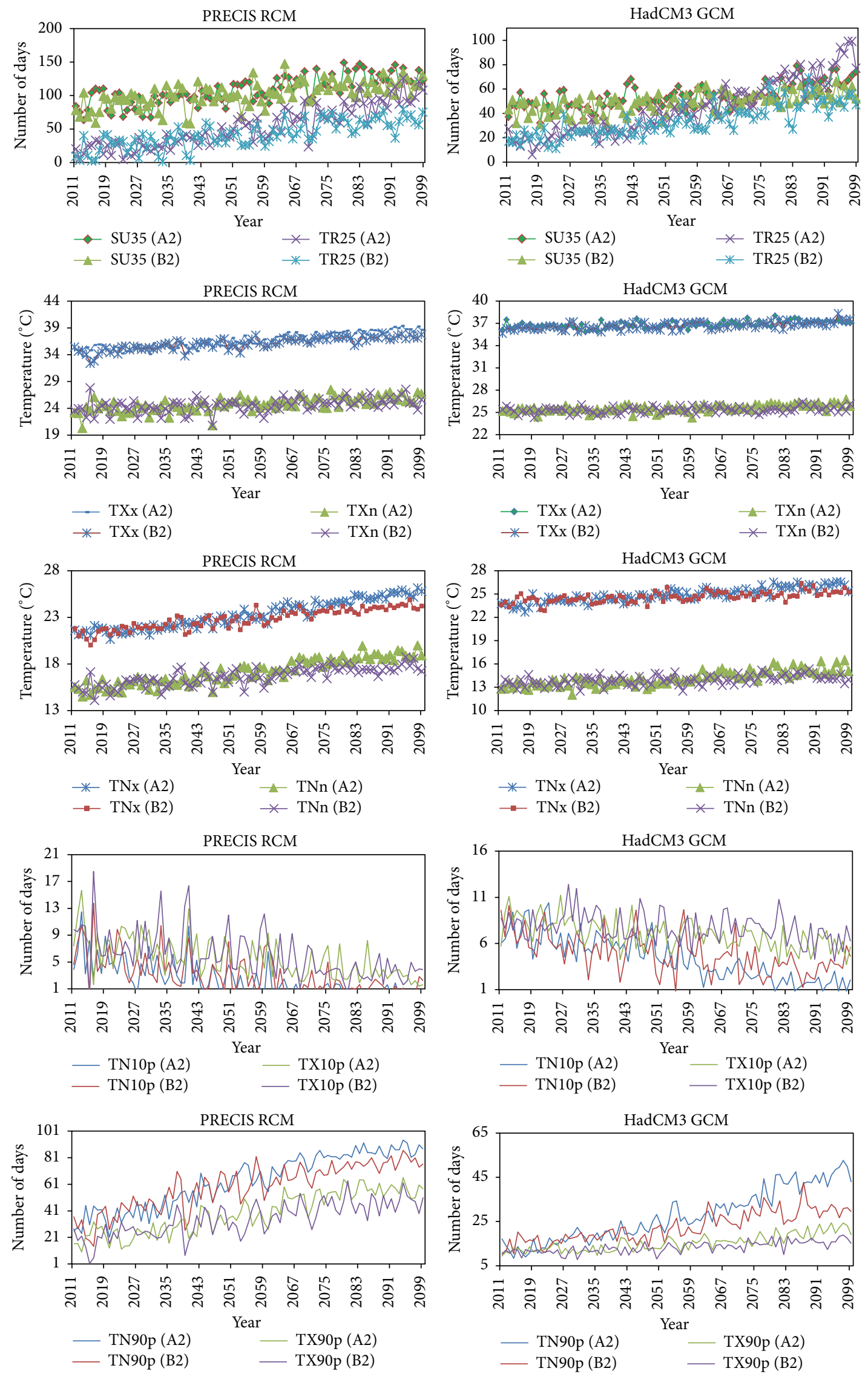

Figure 8: Continued. 

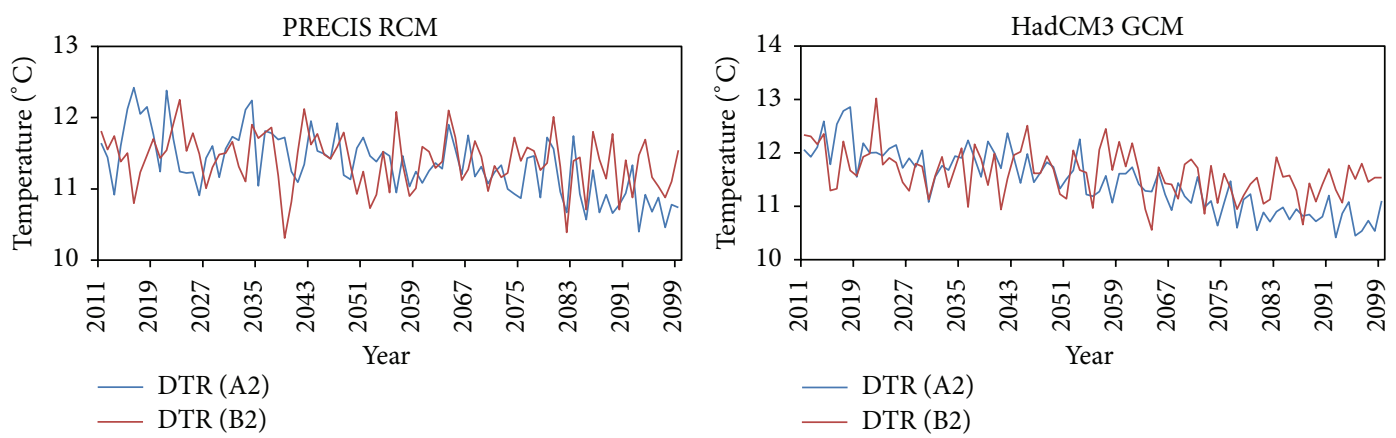

FIGURE 8: Annual series of temperature extremes for Chiang Rai province as predicted by PRECIS RCM and HadCM3 GCM.

TABLE 8: Trend of rainfall indices for 2011-2099 period in Chiang Rai.

\begin{tabular}{lcccc}
\hline $\begin{array}{l}\text { Annual rainfall } \\
\text { series }\end{array}$ & $\begin{array}{c}\text { PRECIS } \\
(\mathrm{A} 2)\end{array}$ & $\begin{array}{c}\text { PRECIS } \\
(\mathrm{B} 2)\end{array}$ & $\begin{array}{c}\text { HadCM3 } \\
(\mathrm{A} 2)\end{array}$ & $\begin{array}{c}\text { HadCM3 } \\
(\mathrm{B} 2)\end{array}$ \\
\hline \multirow{2}{*}{ CDD } & -0.03 & 0.01 & $-5.10^{* * *}$ & $-4.39^{* * *}$ \\
& $(0.000)$ & $(0.000)$ & $(-0.378)$ & $(-0.340)$ \\
CWD & $-2.21^{*}$ & -0.67 & $3.60^{* * *}$ & 0.28 \\
& $(-0.153)$ & $(-0.055)$ & $(0.056)$ & $(0.000)$ \\
PRCPTOT & $3.54^{* * *}$ & 0.89 & $8.43^{* * *}$ & $5.89^{* * *}$ \\
& $(3.834)$ & $(0.958)$ & $(10.278)$ & $(5.801)$ \\
R10 & $1.95^{+}$ & 0.17 & $8.11^{* * *}$ & $5.82^{* * *}$ \\
& $(0.073)$ & $(0.000)$ & $(0.360)$ & $(0.190)$ \\
R20 & $5.99^{* * *}$ & $3.50^{* * *}$ & $7.17^{* * *}$ & $5.21^{* * *}$ \\
& $(0.163)$ & $(0.091)$ & $(0.255)$ & $(0.167)$ \\
R100 & 1.28 & - & 0.00 & 0.00 \\
& $(-)$ & - & $(-)$ & $(-)$ \\
R95P & $3.76^{* * *}$ & 1.64 & $4.49^{* * *}$ & $2.91^{* *}$ \\
& $(3.366)$ & $(1.396)$ & $(2.361)$ & $(1.444)$ \\
R99P & 1.39 & 0.31 & $3.15^{* * *}$ & 1.31 \\
& $(-)$ & $(0.000)$ & $(-)$ & $(-)$ \\
RX1day & $1.68^{+}$ & 0.22 & $2.17^{*}$ & 0.86 \\
& $(0.155)$ & $(0.031)$ & $(0.058)$ & $(0.024)$ \\
RX5day & $5.04^{* * *}$ & 0.61 & $4.79^{* * *}$ & $3.59^{* * *}$ \\
& $(0.315)$ & $(0.128)$ & $(0.388)$ & $(-)$ \\
SDII & 1.82 & 1.61 & $3.13^{* *}$ & 1.85 \\
& $(0.027)$ & $(0.009)$ & $(0.017)$ & $(0.311)$ \\
\hline
\end{tabular}

${ }^{+}$Moderately significant, ${ }^{*}$ significant, ${ }^{* *}$ highly significant, and ${ }^{* * *}$ very highly significant.

compared to that of RX1day. The simple daily intensity index (SDII) is the combined effect of the trend of PRCPTOT and consecutive wet days (CWD). All scenarios of both models predict an increase of SDII with nonsignificant trend except A2 scenario of HadCM3 GCM. Table 9 provides the summary of the statistical analyses of rainfall and temperature indices with their significance for Chiang Mai, Lamphun, and Tak provinces. With some exception especially for rainfall, the future projections for all temperature and rainfall indices are similar to the projection for Chiang Rai Province.

\section{Conclusions}

Our analysis enables a number of conclusions to be drawn as follows:

(1) During observed 1960-2010 period, the entire temperature extremes showed a warming trend which is also supported by the statistical analyses. A warming trend is indicated by the summer days, tropical nights, $\operatorname{Max} T_{\max }, \operatorname{Min} T_{\max }, \operatorname{Max} T_{\min }, \operatorname{Min} T_{\min }$, cool nights, cool days, warm nights, warm days, diurnal temperature range, warm spell duration indicator, and cold spell duration indicator. The warming trend is higher in the southern part of the study area, that is, in Tak. Trend and slope of night extremes (TNx, TNn, TN10, and TN90) appear to have been higher than those in day extremes (TXx, TXn, TX90, and TX10) resulting in the decrease of day-night temperature variation which is also indicated by diurnal temperature range (DTR).

(2) Considering all seasons (winter, spring, summer, and autumn), maximum temperature $\left(T_{\max }\right)$ and minimum temperature $\left(T_{\min }\right)$ have increased significantly in all seasons except spring which is insignificant over the whole study area. Statistical analyses indicated that the increasing trend of $T_{\min }$ was higher than that of $T_{\max }$.

(3) In future, the maximum temperature beyond $35^{\circ} \mathrm{C}$ (summer days) and minimum temperature beyond $25^{\circ} \mathrm{C}$ (tropical nights) will increase with the very high significant trend. For all SRES (A2 and B2) of both models considered in this study, the maximum and minimum temperature increases projected for the period of $2011-2099$ were 0.99 and $0.93^{\circ} \mathrm{C}$ above the observed period. However, monthly maximum and minimum temperature will boost up by 1.56 and $2.24^{\circ} \mathrm{C}$ at the end of this century as compared to the 2020s. In future, all the day, night, cool, and warm extremes will change same as observed period. Diurnal temperature range will go down $\left(0.64^{\circ} \mathrm{C}\right)$ notably over the study area.

(4) During the observed period, annual total rainfall (PRCPTOT) and moderate rainfall (R10) indices were 


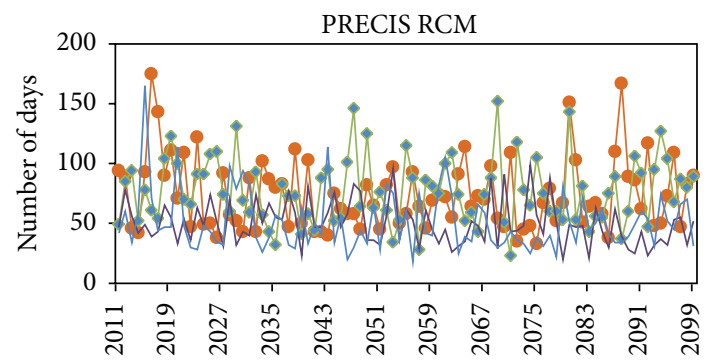

$$
\rightarrow \mathrm{CDD}(\mathrm{A} 2) \quad \mathrm{CWD}(\mathrm{A} 2)
$$$$
\text { - } \mathrm{CDD}(\mathrm{B} 2)-\mathrm{CWD}(\mathrm{B} 2)
$$

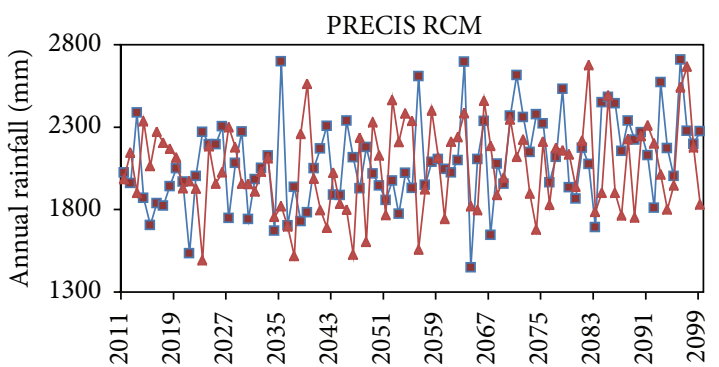

$\rightarrow$ PRCPTOT (A2)

$₫$ PRCPTOT (B2)

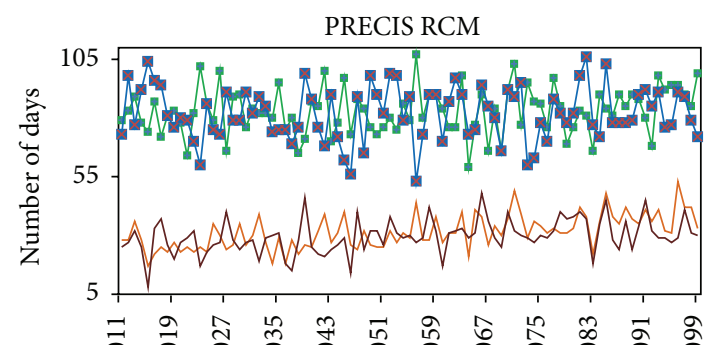

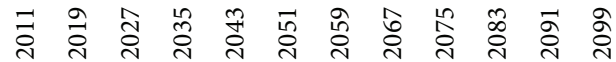

$\rightarrow \mathrm{R} 10(\mathrm{~A} 2) \quad \mathrm{R} 20(\mathrm{~A} 2)$

- R10 (B2) - R20 (B2)

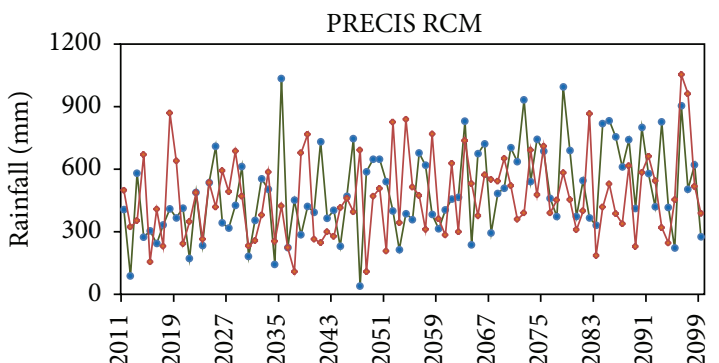

$\rightarrow$ R95P (A2)

$\rightarrow$ R95P (B2)

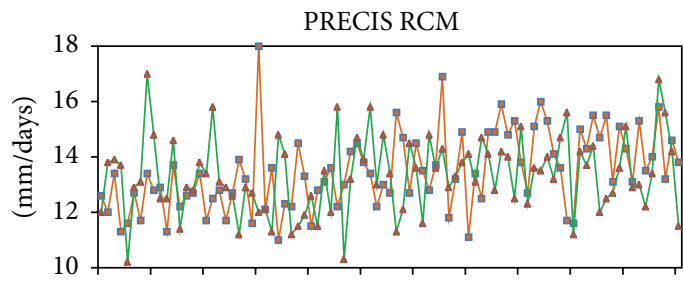

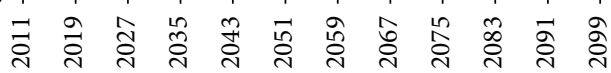

$\rightarrow \operatorname{SDII}(\mathrm{A} 2)$

$\rightarrow$ SDII (B2)

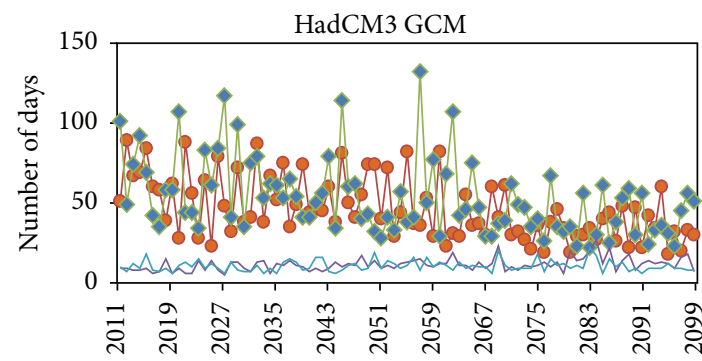

$\rightarrow \operatorname{CDD}(\mathrm{A} 2) \quad$ CWD (A2)

- CDD (B2) CWD (B2)

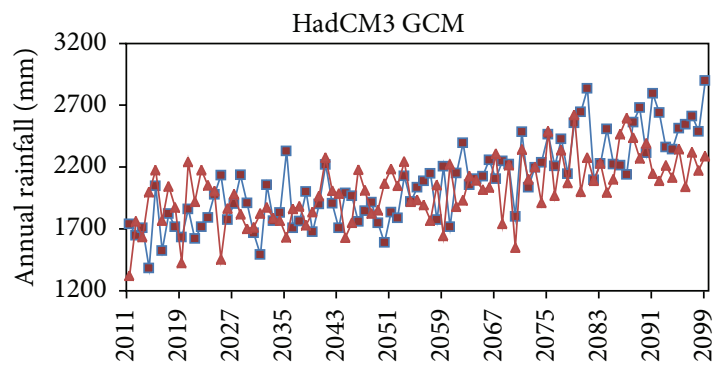

$\because$ PRCPTOT (A2)

$₫$ PRCРTOT (B2)
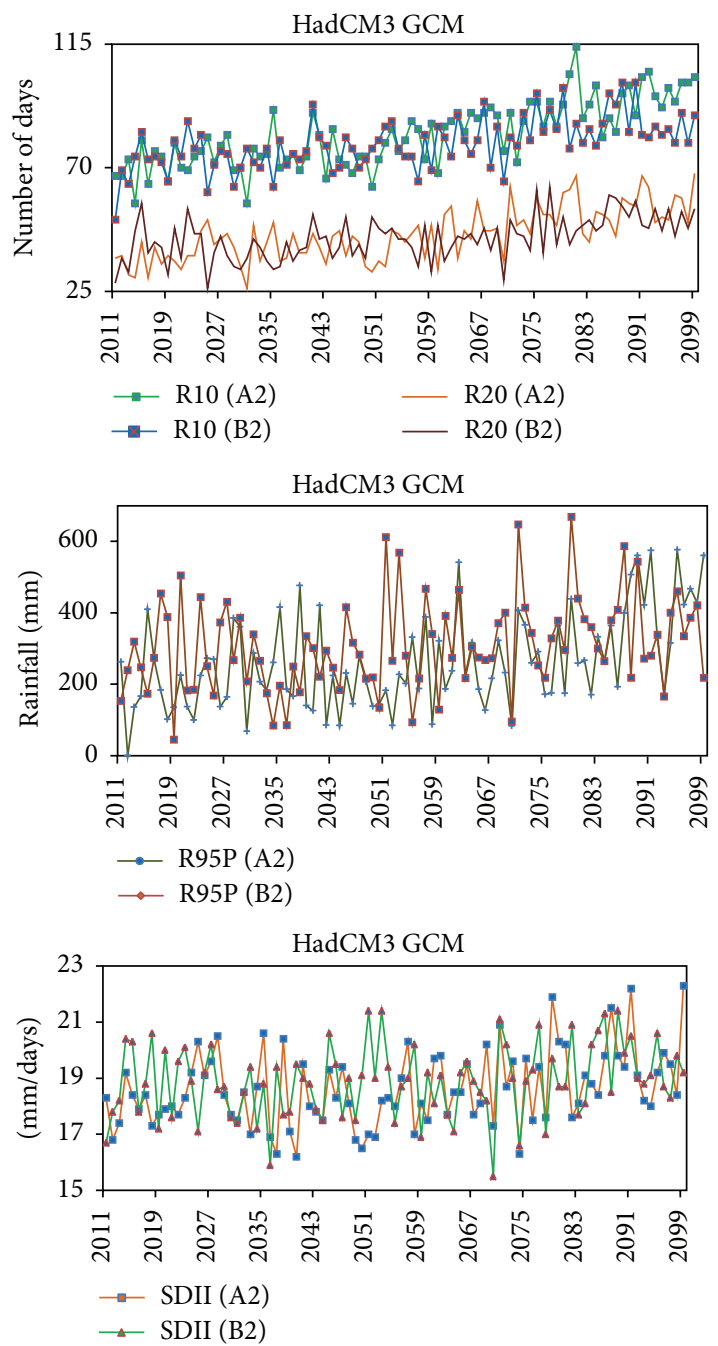

FIGURE 9: Annual series of rainfall extremes for Chiang Rai province as predicted by PRECIS RCM and HadCM3 GCM. 
TABLE 9: Trend of temperature and rainfall indices for 2011-2099 period.

\begin{tabular}{|c|c|c|c|c|c|c|c|c|c|c|c|c|}
\hline \multirow{3}{*}{ Annual series } & \multicolumn{4}{|c|}{ Chiang Mai } & \multicolumn{4}{|c|}{ Lamphun } & \multicolumn{4}{|c|}{ Tak } \\
\hline & \multicolumn{2}{|c|}{ PRECIS } & \multicolumn{2}{|c|}{ HadCM3 } & \multicolumn{2}{|c|}{ PRECIS } & \multicolumn{2}{|c|}{ HadCM3 } & \multicolumn{2}{|c|}{ PRECIS } & \multicolumn{2}{|c|}{ HadCM3 } \\
\hline & $\mathrm{A} 2$ & B2 & $\mathrm{A} 2$ & B2 & $\mathrm{A} 2$ & B2 & $\mathrm{A} 2$ & B2 & $\mathrm{A} 2$ & B2 & $\mathrm{A} 2$ & B2 \\
\hline & \multicolumn{12}{|c|}{ Temperature indices } \\
\hline SU35 & ++ & ++ & ++ & ++ & ++ & ++ & - & - & ++ & ++ & ++ & ++ \\
\hline TR25 & ++ & ++ & ++ & ++ & ++ & ++ & ++ & ++ & ++ & ++ & ++ & ++ \\
\hline TXx & ++ & ++ & ++ & ++ & ++ & ++ & ++ & - & ++ & ++ & ++ & ++ \\
\hline $\mathrm{TNx}$ & ++ & ++ & ++ & ++ & ++ & ++ & ++ & + & ++ & ++ & ++ & ++ \\
\hline TXn & ++ & ++ & ++ & ++ & ++ & ++ & ++ & + & ++ & ++ & ++ & ++ \\
\hline $\mathrm{TNn}$ & ++ & ++ & ++ & ++ & ++ & ++ & ++ & + & ++ & ++ & ++ & ++ \\
\hline TN10p & -- & -- & -- & -- & -- & -- & - & - & -- & -- & - & - \\
\hline TX10p & -- & -- & -- & -- & -- & -- & - & - & -- & -- & -- & -- \\
\hline TN90p & ++ & ++ & ++ & ++ & ++ & ++ & ++ & ++ & ++ & ++ & ++ & ++ \\
\hline TX90p & ++ & ++ & ++ & ++ & ++ & ++ & ++ & ++ & ++ & ++ & ++ & ++ \\
\hline \multirow[t]{2}{*}{ DTR } & -- & - & -- & - & -- & -- & -- & -- & -- & -- & - & - \\
\hline & \multicolumn{12}{|c|}{ Rainfall indices } \\
\hline CDD & + & + & ++ & - & + & - & + & + & + & - & ++ & ++ \\
\hline CWD & - & + & - & -- & - & - & - & - & - & - & + & + \\
\hline PRCPTOT & + & + & - & - & + & - & - & - & + & + & + & + \\
\hline $\mathrm{R} 10$ & - & - & -- & - & + & + & -- & - & + & + & -- & -- \\
\hline R20 & ++ & ++ & + & + & ++ & ++ & - & - & ++ & ++ & - & - \\
\hline R95P & ++ & ++ & ++ & + & ++ & ++ & - & - & ++ & + & + & - \\
\hline SDII & + & ++ & ++ & ++ & ++ & ++ & - & - & + & ++ & ++ & ++ \\
\hline
\end{tabular}

+ positive trend, - negative trend, and statistical significant trend $(++,--)$ signs.

decreased which is supported by the negative trend of consecutive wet days (CDD). However, none of the indices showed significant trend in the observed period and there was no significant trend found for seasonal rainfall also. Each model and scenario evaluated project an increase in average annual rainfall of 9.65\% for 2011-2099 compared to the observed annual rainfall $1235 \mathrm{~mm}$.

Topographic changes of the earth greatly influence the variation of climatic parameters and their extremes and anomalies. Hence, it is recommended to explore the changes of climate extremes and their anomalies over topography using a large number of stations.

\section{Conflict of Interests}

The authors declare that there is no conflict of interests regarding the publication of this paper.

\section{Acknowledgments}

The authors would like to acknowledge the financial support from Asian Development Bank and Japan Scholarship Program (ADB-JSP) to finish this research work. Thanks to Jannatul Ferdous for her help in data analysis which helped the authors to finish this work.

\section{References}

[1] IPCC, Climate Change 2007. The Physical Science Basis, Contribution of Working Group I to the Fourth Assessment Report of the Intergovernmental Panel on Climate Change, Cambridge University Press, Cambridge, UK, 2007.

[2] C. Tebaldi, K. Hayhoe, J. M. Arblaster, and G. A. Meehl, "Going to the extremes-an intercomparison of model-simulated historical and future changes in extreme events," Climatic Change, vol. 79, no. 3-4, pp. 185-211, 2006.

[3] J. Alcamo, N. Dronin, M. Endejan, G. Golubev, and A. Kirilenko, "A new assessment of climate change impacts on food production shortfalls and water availability in Russia," Global Environmental Change, vol. 17, no. 3-4, pp. 429-444, 2007.

[4] R. P. Allan and B. J. Soden, "Atmospheric warming and the amplification of precipitation extremes," Science, vol. 321, no. 5895, pp. 1481-1484, 2008.

[5] J. H. Christensen, B. Hewitson, A. Busuioc et al., "Regional climate projections," in Climate Change 2007: The Physical Science Basis. Contribution of Working Group I to the Fourth Assessment Report of the Intergovernmental Panel on Climate Change, S. Solomon, D. Qin, M. Manning et al., Eds., Cambridge University Press, Cambridge, UK, 2007.

[6] H. Kettle and R. Thompson, "Statistical downscaling in European mountains. Verification of reconstructed air temperature," Climate Research, vol. 26, no. 2, pp. 97-112, 2004.

[7] R. L. Wilby, T. M. L. Wigley, D. Conway et al., "Statistical downscaling of general circulation model output: a comparison of 
methods," Water Resources Research, vol. 34, no. 11, pp. 29953008, 1998.

[8] F. Bouraoui, G. Vachaud, L. Z. X. Li, H. Le Treut, and T. Chen, "Evaluation of the impact of climate changes on water storage and groundwater recharge at the watershed scale," Climate Dynamics, vol. 15, no. 2, pp. 153-161, 1999.

[9] P. Frich, L. V. Alexander, P. Della-Marta et al., "Observed coherent changes in climatic extremes during the second half of the twentieth century," Climate Research, vol. 19, no. 3, pp. 193-212, 2002.

[10] L. V. Alexander, X. Zhang, T. C. Peterson et al., "Global observed changes in daily climate extremes of temperature and precipitation," Journal of Geophysical Research: Atmospheres, vol. 111, no. 5, Article ID D05109, 2006.

[11] B. Orlowsky and S. I. Seneviratne, "Global changes in extreme events: regional and seasonal dimension," Climatic Change, vol. 110, no. 3-4, pp. 669-696, 2012.

[12] M. G. Donat, L. V. Alexander, H. Yang et al., "Updated analyses of temperature and precipitation extreme indices since the beginning of the twentieth century: the HadEX2 dataset," Journal of Geophysical Research: Atmospheres, vol. 118, no. 5, pp. 2098-2118, 2013.

[13] M. J. Manton, P. M. Della-Marta, M. R. Haylock et al., "Trends in extreme daily rainfall and temperature in southeast Asia and the south Pacific: 1961-1998," International Journal of Climatology, vol. 21, no. 3, pp. 269-284, 2001.

[14] G. M. Griffiths, L. E. Chambers, M. R. Haylock et al., "Change in mean temperature as a predictor of extreme temperature change in the Asia-Pacific region," International Journal of Climatology, vol. 25, no. 10, pp. 1301-1330, 2005.

[15] S. Chinvanno, V. Luang-Aram, C. Saengmanee, and J. Thanakitmetavut, Developing High Resolution Climate Scenarios for Southeast Asia Region and Mekong River Basin for 19602100, SEA START Regional Centre, Bangkok, Thailand, 2011, http://startcc.iwlearn.org/doc/Doc_eng_10.pdf.

[16] J. Kreasuwan, "Simulation of future climate scenario for Thailand," Tech. Rep., Thailand Research Fund, Bangkok, Thailand, 2009, http://startcc.iwlearn.org/doc/Doc_eng_15.pdf.

[17] Southeast Asia START Regional Center, Preparation of Climate Change Scenarios for Climate Change Impact Assessment in Thailand, Southeast Asia START Regional Center, 2011, http://startcc.iwlearn.org/doc/Doc_eng_15.pdf.

[18] H. S. Lim, K. Boochabun, and A. D. Ziegler, "Modifiers and amplifiers of high and low flows on the Ping river in Northern Thailand (1921-2009): the roles of climatic events and anthropogenic activity," Water Resources Management, vol. 26, no. 14, pp. 4203-4224, 2012.

[19] J. Fox, J. B. Vogler, O. L. Sen, T. W. Giambelluca, and A. D. Ziegler, "Simulating land-cover change in Montane Mainland Southeast Asia," Environmental Management, vol. 49, no. 5, pp. 968-979, 2012.

[20] S. Sangawongse, "Land-use/land-cover dynamics in Chiang Mai: appraisal from remote sensing, GIS and modeling approaches," CMU Journal, vol. 5, no. 2, pp. 243-254, 2006.

[21] L. Lebel, P. Garden, N. Subsin, and S. Na Nan, "Averted crises, contested transitions: water management in the Upper Ping River basin, Northern Thailand," in Water Policy Entrepeneurs. A Research Companion to Water Transitions Around the Globe, D. Huitema and S. Meijerink, Eds., pp. 137-157, Edward Elgar, Cheltenham, UK, 2009.
[22] S. Sangawongse, S. Prabudhanitisarn, and E. Karjagthimaporn, "Agricultural land use change and urbanization in Thailand," in Proceedings of the UM Conference, 2011.

[23] J. Rigg and M. Ritchie, "Production, consumption and imagination in rural Thailand," Journal of Rural Studies, vol. 18, no. 4, pp. 359-371, 2002.

[24] W. Jompakdee, "Rivers in jeopardy and the role of civil society in river restoration: Thai experiences," CMU Journal, vol. 3, no. 1, pp. 59-71, 2004.

[25] EPSEA, "Adapting to floods in Chiang Mai: confronting the gaps," EEPSEA Climate Change Policy Brief no. 2010CC-PB6, 2010.

[26] S. H. Wood and A. D. Ziegler, "Floodplain sediment from a 100 -year-recurrence flood in 2005 of the Ping River in northern Thailand," Hydrology and Earth System Sciences, vol. 12, no. 4, pp. 959-973, 2008.

[27] A. D. Ziegler, "Water management: reduce urban flood vulnerability," Nature, vol. 481, no. 7380, p. 145, 2012.

[28] A. D. Ziegler, L. H. She, C. Tantasarin, N. R. Jachowski, and R. Wasson, "Floods, false hope, and the future," Hydrological Processes, vol. 26, no. 11, pp. 1748-1750, 2012.

[29] Thai Meteorological Department, The Climate of Thailand, 2015, http://tmd.go.th/en/archive/thailand_climate.pdf.

[30] R. L. Wilby, C. W. Dawson, and E. M. Barrow, "SDSM-a decision support tool for the assessment of regional climate change impacts," Environmental Modelling and Software, vol. 17, no. 2, pp. 147-157, 2002.

[31] B. C. Hewitson and R. G. Crane, "Climate downscaling. Techniques and application," Climate Research, vol. 7, no. 2, pp. 8595, 1996.

[32] E. Kalnay, M. Kanamitsu, R. Kistler et al., "The NCEP/NCAR 40-year reanalysis project," Bulletin of the American Meteorological Society, vol. 77, no. 3, pp. 437-471, 1996.

[33] R. L. Wilby, C. W. Dawson, and E. M. Barrow, "SDSM-a decision support tool for the assessment of regional climate change impacts," Environmental Modelling and Software, vol. 17, no. 2, pp. 147-159, 2002.

[34] U. Cubasch, G. A. Meehl, G. J. Boer et al., "Projections of future climate change," in Climate Change 2001. The Scientific Basis, J. T. Houghton, Y. Ding, D. J. Griggs et al., Eds., pp. 525-582, Cambridge University Press, New York, NY, USA, 2001.

[35] R. Fealy and J. Sweeney, "Statistical downscaling of precipitation for a selection of sites in Ireland employing a generalised linear modelling approach," International Journal of Climatology, vol. 27, no. 15, pp. 2083-2094, 2007.

[36] C. J. R. Williams, D. R. Kniveton, and R. Layberry, “Assessment of a climate model to reproduce rainfall variability and extremes over Southern Africa," Theoretical and Applied Climatology, vol. 99, no. 1-2, pp. 9-27, 2010.

[37] L. Tryhorn and A. DeGaetano, "A comparison of techniques for downscaling extreme precipitation over the Northeastern United States," International Journal of Climatology, vol. 31, no. 13, pp. 1975-1989, 2011.

[38] IPCC, Special Report on Emissions Scenarios: A Special Report of Working Group III of the Intergovernmental Panel on Climate Change, Cambridge University Press, Cambridge, UK, 2000.

[39] H. B. Mann, "Nonparametric tests against trend," Econometrica, vol. 13, pp. 245-259, 1945.

[40] M. G. Kendall, Rank Correlation Methods, Hafner Publishing, New York, NY, USA, 1948. 
[41] L. Zongxing, Y. He, P. Wang et al., "Changes of daily climate extremes in southwestern China during 1961-2008," Global and Planetary Change, vol. 80-81, pp. 255-272, 2012.

[42] S. Yue, P. Pilon, and G. Cavadias, "Power of the Mann-Kendall and Spearman's rho tests for detecting monotonic trends in hydrological series," Journal of Hydrology, vol. 259, no. 1-4, pp. 254-271, 2002.

[43] V. D. P. R. daSilva, "On climate variability in Northeast of Brazil," Journal of Arid Environments, vol. 58, no. 4, pp. 575-596, 2004.

[44] Q. Liu, Z. Yang, and B. Cui, "Spatial and temporal variability of annual precipitation during 1961-2006 in Yellow River Basin, China," Journal of Hydrology, vol. 361, no. 3-4, pp. 330-338, 2008.

[45] L. V. Alexander and J. M. Arblaster, "Assessing trends in observed and modelled climate extremes over Australia in relation to future projections," International Journal of Climatology, vol. 29, no. 3, pp. 417-435, 2009.

[46] L. Liang, L. Li, and Q. Liu, "Temporal variation of reference evapotranspiration during 1961-2005 in the Taoer River basin of Northeast China," Agricultural and Forest Meteorology, vol. 150, no. 2, pp. 298-306, 2010.

[47] J. A. Marengo, L. M. Alves, W. R. Soares et al., "Two contrasting seasonal extremes in tropical South America in 2012: flood in Amazonia and drought in Northeast Brazil," Journal of Climate, vol. 26, pp. 9137-9154, 2013.

[48] P. K. Sen, "Estimates of the regression coefficient based on Kendall's tau," Journal of the American Statistical Association, vol. 63, pp. 1379-1389, 1968.

[49] V. L. Tran, D. C. Hoang, and T. T. Tran, "Building of climate change scenario for Red River catchments for sustainable development and environmental protection," in Proceedings of the Science Workshop on Hydrometeorological Change in Vietnam and Sustainable Development, pp. 70-82, Ministry of Natural Resource and Environment, Hanoi, Vietnam, 2005.

[50] D. Sharma and M. S. Babel, "Trends in extreme rainfall and temperature indices in the western Thailand," International Journal of Climatology, vol. 34, no. 7, pp. 2393-2407, 2014.

[51] X. B. Zhang, E. Aguilar, S. Sensoy et al., "Trends in Middle East climate extreme indices from 1950 to 2003," Journal of Geophysical Research: Atmospheres, vol. 110, no. 22, Article ID D22104, 2005.

[52] X. Liu, Z. Cheng, L. Yan, and Z.-Y. Yin, "Elevation dependency of recent and future minimum surface air temperature trends in the Tibetan Plateau and its surroundings," Global and Planetary Change, vol. 68, no. 3, pp. 164-174, 2009.

[53] P. Deb and M. S. Babel, "Assessment of impact of climate change and adaptation measures for maize production in East Sikkim, India," Journal of Hydrology and Meteorology, vol. 9, no. 1, pp. 15-27, 2015.

[54] L. Erda, X. Wei, J. Hui et al., "Climate change impacts on crop yield and quality with $\mathrm{CO}_{2}$ fertilization in China," Philosophical Transactions of the Royal Society B: Biological Sciences, vol. 360, no. 1463, pp. 2149-2154, 2005.

[55] G. A. Meehl, T. F. Stocker, W. D. Collins et al., "Global climate projections," in Climate Change 2007. The Physical Science Basis, S. Solomon, D. Qin, M. Manning et al., Eds., Contribution of Working Group I to the Fourth Assessment Report of the Intergovernmental Panel on Climate Change, Cambridge University Press, Cambridge, UK, 2007.

[56] V. Cruz Rex, H. Hideo, L. Murari et al., "In climate change 2007. Impacts, adaptation and vulnerability," in Working Group
II to the 4th Assessment Report of the Intergovernmental Panel on Climate Change, M. L. Parry, O. F. Canziani, J. P. Palutikof, P. J. van der Linden, and C. E. Hanson, Eds., pp. 469-506, Cambridge University Press, Cambridge, UK, 2007.

[57] A. G. Reda, N. K. Tripathi, P. Soni, T. Tipdecho, and A. Phalke, "Temporal climate trend of Ping basin of Thailand and implications for Mekong Region," Journal of Earth Science and Climatic Change, vol. 4, article 146, 2013. 

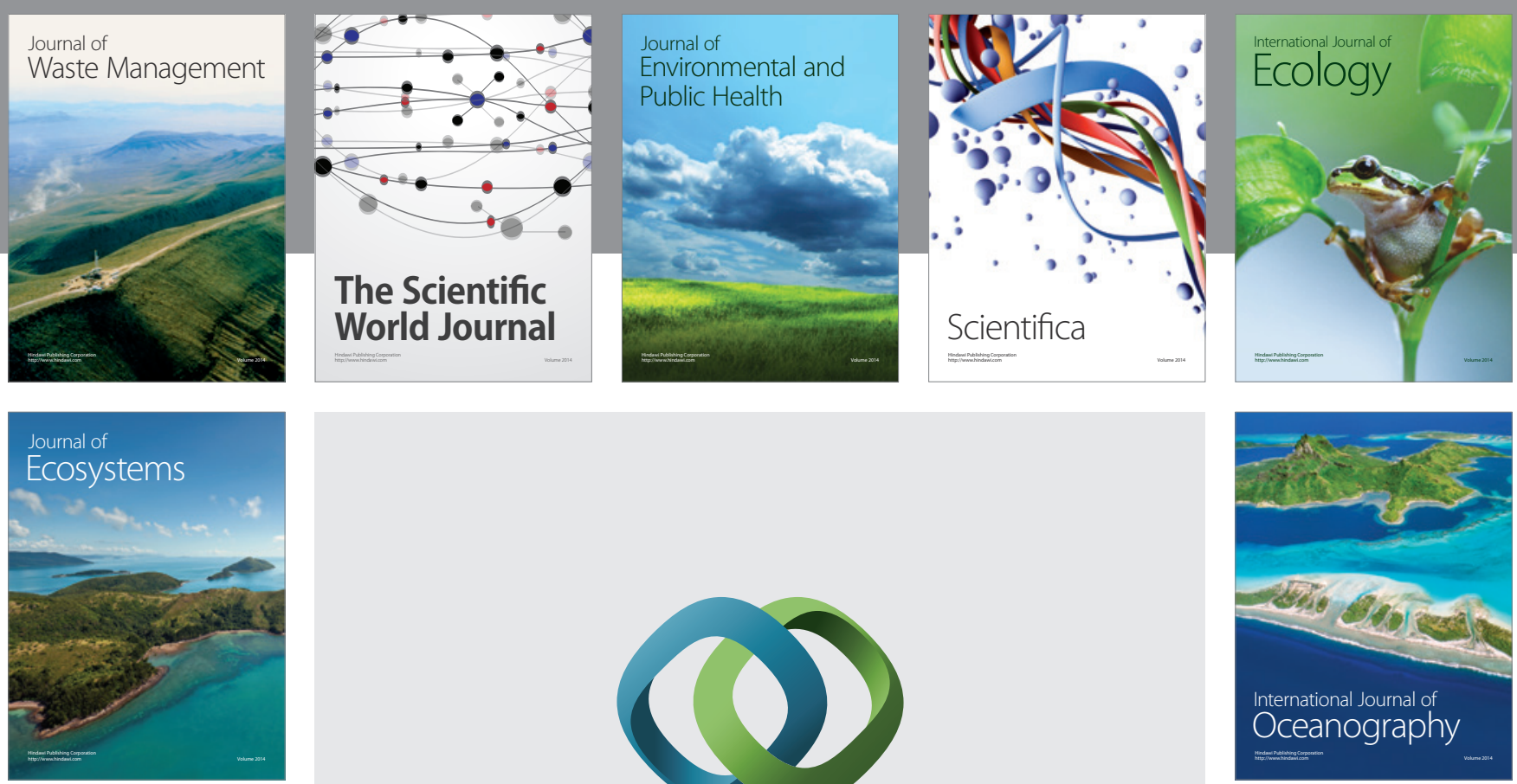

The Scientific World Journal
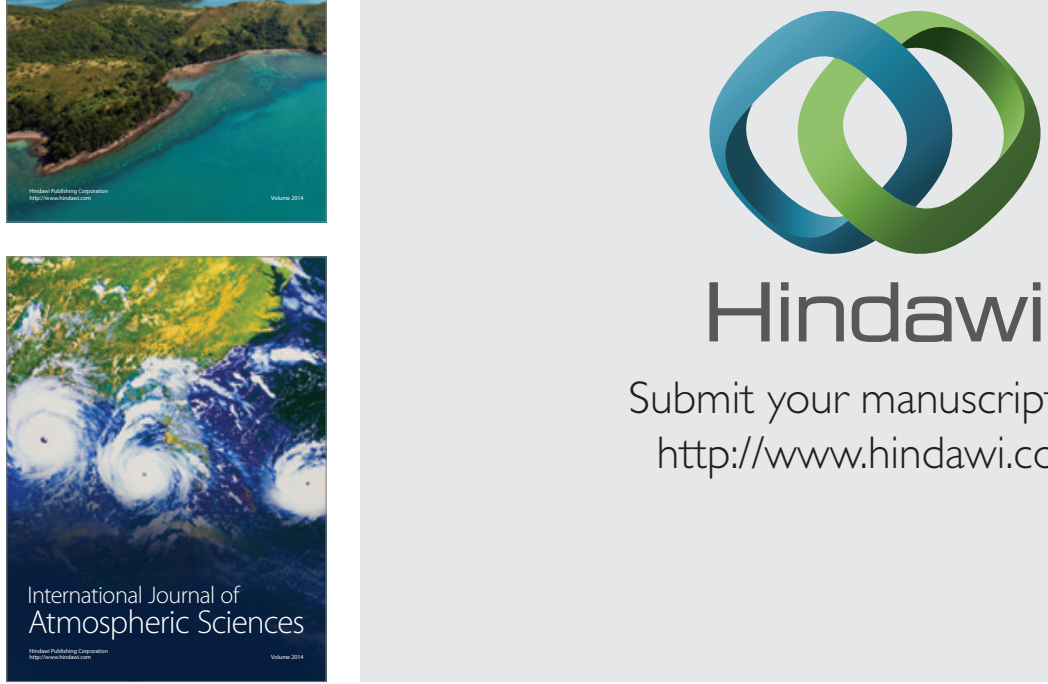

\section{Hindawi}

Submit your manuscripts at

http://www.hindawi.com
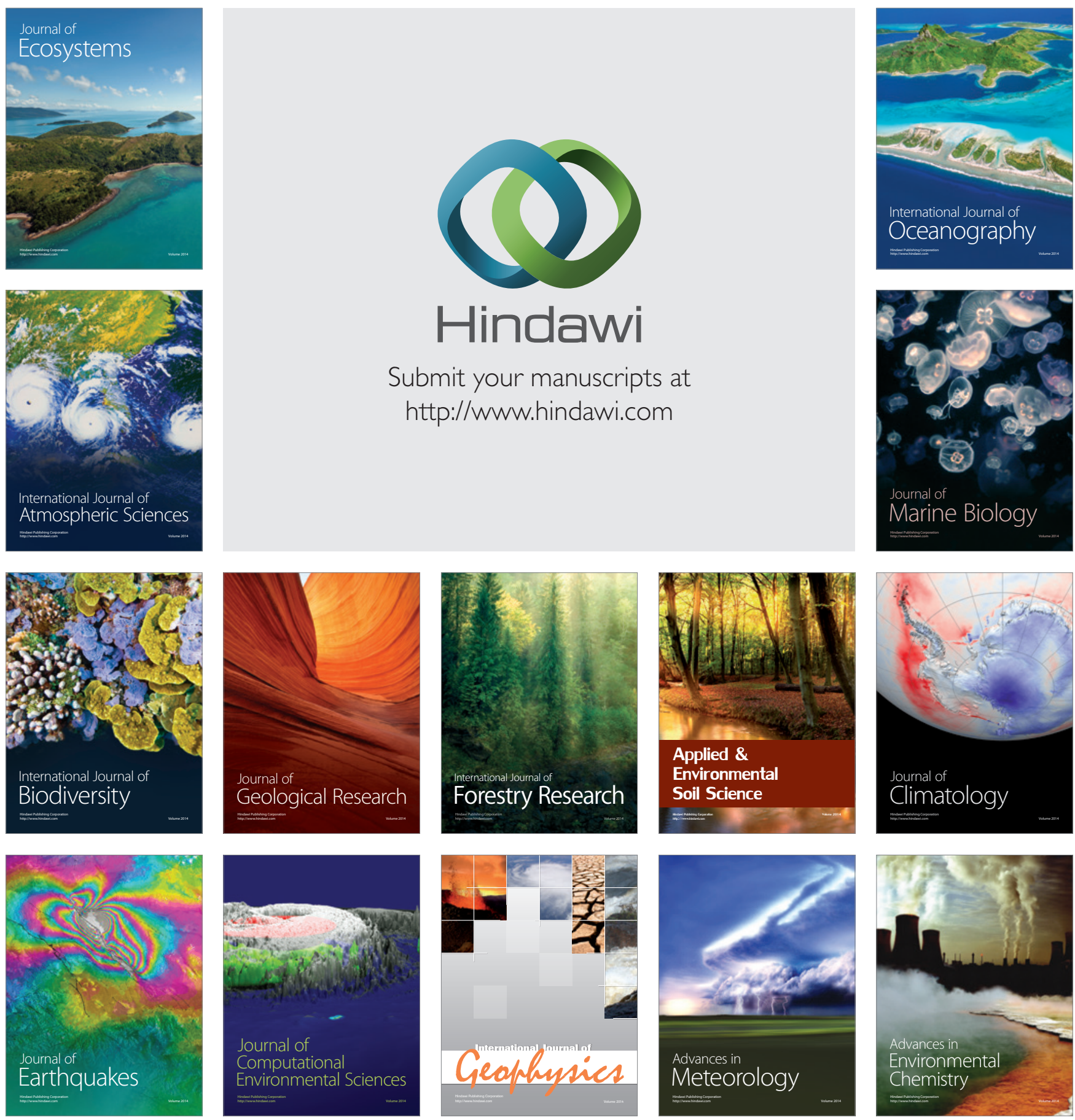